\title{
BIOPIRATARIA: REFLEXÕES SOBRE UM TIPO PENAL
}

BIOPIRACY: REFLECTION ABOUT THE ESTABLISHMENT OF A SPECIFIC CRIMINAL OFFENSE

\author{
Ivanira Pancheri*
}

\begin{abstract}
Resumo:
Cinge-se ao tema Biopirataria reflexionando sob a criação de um respectivo tipo penal. Não-obstante a ausência de uma conceituação jurídica uníssona sobre Biopirataria parte-se da concepção primordial de um acesso irregular ao Patrimônio Genético e, ainda, aos Conhecimentos Tradicionais associados. Não se olvide todavia que, ao lado destes grandes nortes, comportamentos outros igualmente conformam a problemática, demandando coibição, ad exemplum, a não-repartição dos benefícios, ou ainda, a anormalidade no uso do Patrimônio Genético ou dos Conhecimentos Tradicionais associados, na remessa para o Exterior, no transporte e armazenamento do Patrimônio Genético, na divulgação dos Conhecimentos Tradicionais associados e, enfim, variadas condutas contra a Administração da Biodiversidade. Sob uma metodologia monotemática, teórica e científica, investigase infindável material bibliográfico para solver assunto contemporâneo e político. A partir de duas premissas, quais sejam, o princípio do menor custo moral que funda eticamente toda a altercação sobre a interação homem e natureza e ainda, o inestimável valor do fato avaliado que justifica a incidência do Direito Penal, alcançou-se a ilação acerca da imprescindibilidade de um respectivo tipo penal. Destarte, o deslinde é no sentido de uma incriminação, cujo Bem Jurídico Penal capital sagra-se como sendo a Biodiversidade, perfilhada esta como a diversidade biológica, sem esquecer contudo, de todo um cogente arcabouço tanto jurídico nacional e internacional quanto socioeconômico para ofertar amparo à resolução desta controvérsia.
\end{abstract}

Palavras-chave: Biopirataria. Patrimônio genético. Conhecimentos tradicionais associados. Biodiversidade. Tipo penal.

\begin{abstract}
:
This paper is about biopiracy, including a reflection about the establishment of a specific criminal offense. Despite the absence of a unique legal concept of biopiracy, it starts from the primordial conception of an irregular access to Genetic Heritage and also to its associated traditional knowledge. It should not forget however that, along these two main guidelines, there are other types of behaviors that comprehend this problem, which demand restraints, ad exemplum: no share of benefits, or even, abnormal use of genetic heritage and of its associated traditional knowledge in the remittance abroad, in the transport and the storage of genetic heritage, in the dissemination of associated traditional knowledge and, finally, in various procedures which are against the governance of biodiversity. According to the theoretical, scientific and monothematic methodology, and endless bibliographic material to settle this contemporary political issue was researched. From two premises, namely,
\end{abstract}

Doutora pela Faculdade de Direito da Universidade de São Paulo em Direito Penal. Mestre pela Faculdade de Direito da Universidade de São Paulo em Direito Processual Penal. Especialista em Direito Ambiental pelas Faculdades Metropolitanas Unidas. Procuradora do Estado de São Paulo. Docente. 
the principle of the lower moral cost on which are based, ethically speaking, all altercation on the interaction between man and nature and also the priceless value of the evaluated fact, which justifies the incidence of criminal law, a conclusion was reached, and it is regarding the indispensability of a exact criminal offense. Thus, the inquiry is regarding criminality, whose capital legal goods are consecrated as being biodiversity, endorsed as biological diversity, without forgetting, however, an entire cogent framework both of the national and international judicial branches and of the socio-economic development to offer support to the resolution of this controversy.

Keywords: Biopiracy. Genetic resources. Associated traditional knowledge. Biodiversity. Specific criminal offense.

\section{Introdução}

Há anos discute-se a questão da Biopirataria lato sensu, que engloba a exploração e o comércio ilegais de madeira, o tráfico de animais e plantas silvestres e especificamente, o assunto a ser tratado neste artigo científico, qual seja, a Biopirataria stricto sensu, compreendida como o acesso irregular ao patrimônio genético nacional e aos conhecimentos tradicionais associados.

No que concerne à Biopirataria em sentido estrito, quatro dimensões caracterizam-na: recurso genético obtido sem a autorização do detentor (Estados Nacionais); conhecimento tradicional associado conseguido sem autorização do detentor (sem conhecimento prévio fundamentado); benefícios alcançados pela utilização do recurso genético e do conhecimento tradicional associado (prioritariamente exploração comercial) não repartidos de forma justa e equitativa entre Estados, corporações e comunidades (sem contrato); e por fim, recursos biológicos protegidos sem respeito aos critérios de patenteabilidade, isto é, sem representar novidade, inventividade e uso industrial nos moldes do Tratado Sobre Direitos de Propriedade Intelectual Relacionado a Aspectos de Comércio (do inglês Agreement on Trade-Related Aspects of Intellectual Property Rights, TRIPS).

A temática abordada, por conseguinte será: Biopirataria stricto sensu ou biogrilagem qualificando-a como: toda apropriação e uso não autorizados de material biológico e/ou de conhecimentos tradicionais associados, para fins de desenvolvimento e comercialização de produtos, podendo ou não envolver obtenção de direitos de propriedade intelectual.

E, primordialmente, ao conceituar-se Biopirataria, ponderar-se-á a necessidade de considerá-la infração penal ou não porque a legislação como um todo é lacunosa, inexistindo tipificação do crime de Biopirataria, o que induziria à aplicação, tão apenas de forma subsidiária e incipiente, da Lei de Crimes Ambientais (Lei n. 9.605/98).

Em verdade, a Biopirataria incide há séculos. 
No que pertence à Biopirataria stricto sensu, a extração de pigmento vermelho do pau-brasil pelos portugueses à época do descobrimento já a configurava. $\mathrm{O}$ ato seguinte de biopirataria ocorre na Amazônia, com o envio de sementes de seringueira para a Inglaterra, por Henry Wickham, em 1876, arruinando o ciclo da borracha em razão da posterior exportação do látex pelas colônias britânicas na Malásia. Outro exemplo é a quinina, derivada da planta cinchona, empregada para o tratamento da malária, pelos povos indígenas. Foi traficada para Java, pelo inglês Charles Ledger, em 1865. Também, o curare, amálgama tóxico de várias plantas, usado para o envenenamento das pontas de flechas, por etnias da Amazônia. Exportado para a Europa, por Alexander von Humbolt, em 1800, teve seu ingrediente ativo (tubocurarina) isolado para fins anestésicos.

E, no panorama coevo, o rol exemplificativo da Biopirataria é largo, podendo-se fazer referência aos episódios abarcando a Castanha-do-pará, a Ayahuasca (principal planta empregada nos rituais do Santo Daime), a Espinheira-Santa, a Unha-degato, a Vacina do Sapo, dentre muitos outros.

Quanto às marcas "cupuaçu” e "cupulate", bem como às patentes mundiais sobre a extração do óleo do cupuaçu e a produção de cupulate, convém recordar que já estavam registradas na União Europeia, Japão e nos Estados Unidos pela empresa japonesa Asahi Foods, o que implicou em campanha nacional "O cupuaçu é nosso!".

A Biopirataria, contudo, apenas recentemente se elevou à grandeza de temática estratégica.

Se antigamente, a segurança da Biodiversidade cravava-se em valores científicos, estéticos e de lazer, que pautavam ações de preservação de simpáticas espécies e delimitação de áreas da natureza de beleza exuberante, com a consequente retirada das populações locais e a expropriação de seus conhecimentos, em décadas passadas, há mudança do paradigma, percebendo-se a importância econômica da biodiversidade.

Noutras palavras, uma das mais preocupantes perdas ambientais é aquela que diz respeito à falência da diversidade biológica, ${ }^{1}$ imprimindo ao país reforçar a conservação dos recursos genéticos e a sustentabilidade de seus bens.

Em acréscimo, convém lembrar que, hodiernamente, é real o perigo de em poucos anos, tal situação de detrimento da Biodiversidade apor o homem a calamidades

\footnotetext{
1 "É comum citar-se uma ilustração do que significam as altas taxas de perda de biodiversidade global: é como se estivéssemos dançando em um antiquário com as luzes apagadas, é possível ouvir-se o barulho de coisas que se quebram, mas não se pode saber o tamanho do prejuízo, até que seja tarde demais. Esta metáfora, apesar de ser bastante representativa do percurso humano inconseqüente em relação à biodiversidade, deixa de expressar a face ainda mais dramática da realidade, uma vez que, na imagem, o dono do antiquário sabe o valor de suas mercadorias e, portanto pode avaliar o quanto perdeu, enquanto o valor da perda da biodiversidade é incalculável." (ALENCAR, Gisela S. de. Biopolítica, biodiplomacia e a Convenção sobre Diversidade Biológica 1992: evolução e desafios para implementação. Revista de Direito Ambiental, São Paulo, v. 3, n. 1, p. 82-103, set. 1996, p. 84).
} 
ambientais, não havendo que se falar sequer em responsabilidade intergeracional. Noutras palavras, se houver uma crise de biodiversidade, nossa vida, saúde e meios de subsistência também entrarão em colapso.

Assim, a intranquilidade com a problemática ambiental já deve ser concebida como um risco para a atual qualidade de vida e à própria vida. $\mathrm{E}$, o exaurimento da genética ou, por outro lado, sua coisificação quando do patenteamento ${ }^{2}$ e ainda, a transcrita perda da diversidade em razão da crise do meio ambiente, devem tornar-se assuntos confinantes.

Prosseguindo. De sabença, o Brasil cobre enorme diversidade biológica, sendo tido como o país mais megadiverso do mundo, ${ }^{3}$ compreendido o conceito atual de Biodiversidade como as inúmeras variedades estrutural e funcional de formas de vida nos níveis genético, populacional, das espécies e dos ecossistemas.

Com três milhões e cinquenta e sete mil quilômetros quadrados de florestas tropicais, ou seja, trinta por cento das florestas tropicais do mundo, e abrigando a maior delas, isto é, a Floresta Amazônica, o Brasil tem em seu território quase vinte por cento de todas as espécies da flora e fauna já reconhecidas e sete áreas catalogadas pela Organização das Nações Unidas para a Educação, a Ciência e a Cultura (UNESCO) como Sítios do Patrimônio Mundial Natural. ${ }^{4}$

Assim, existe um gigantesco patrimônio genético - inclusive desconhecido - que, se bem explorado do ponto de vista econômico, social e ambiental, pode contribuir amplamente para o processo de desenvolvimento do país, não se olvidando de seu valor intrínseco.

Pois bem, grande parte dessa riqueza encontra-se presente nos biomas da Floresta Amazônica e também, da Mata Atlântica. Numa visão breve portanto, o potencial florístico e a fauna associada a essas vegetações já constituiria inigualável complexo de bens.

As perdas de cobertura florestal primária em todo o mundo beiram, em geral, entre os dois terços e a quase totalidade. No país, a Mata Atlântica e a Amazônia

2 Ver regulação do art. 10, inciso IX, da Lei da Propriedade Industrial (Lei n. 9.279/96) e, por outro lado, as iniciativas legislativas em tramitação no Congresso Nacional (PL n. 2.695/93 e outros) acerca da patenteabilidade ou não do todo ou parte de seres vivos naturais e materiais biológicos encontrados na natureza, ou ainda que dela isolados, inclusive o genoma ou germoplasma de qualquer ser vivo natural e os processos naturais.

3 CÂMARA DOS DEPUTADOS. Comissão Parlamentar de Inquérito que Investiga o Tráfico de Animais e Plantas Silvestres Brasileiras, a Exploração e Comércio Ilegal de Madeira e a Biopirataria no País (CPIBIO). Relatório final/2006. Disponível em: <http://camara.gov.br/comissoes.htm>. Acesso em: 23 out. 2007.

4 Cf. Lista do Patrimônio Mundial no Brasil. 
já sucumbiram respectivamente, em noventa e três por cento desde o período colonial ${ }^{5}$ e dezesseis por cento em apenas trinta anos.

Forçoso é salientar a premência de uma estratégia de guerra contra a derrubada de árvores e consequentemente, o fim de Biodiversidade ignorada, animal, vegetal e de microrganismos.

Há de conseguir-se, portanto, um modelo sustentável.

Por fim, neste ínterim, surge o debate sobre a proteção aos Conhecimentos Tradicionais associados.

Assim, há de adicionar a essa diversidade biológica um outro dado que a potencializa: a existência de populações nativas, sejam elas indígenas (no Brasil, há cerca de setecentas terras indígenas, representando mais de doze por cento do território nacional, totalizando cerca de trezentos e quarenta mil índios, distribuídos entre duzentos e vinte sociedades indígenas, e inda, mais de setenta grupos de índios isolados sem outras informações objetivas), ${ }^{6}$ ribeirinhas, caboclas, remanescentes quilombolas e outras. É a Sociodiversidade.

Capacitadas por um conhecimento milenar, tais povos empreendem práticas tradicionais de uso sustentável dos recursos naturais, usando os princípios ativos de certas substâncias para fins inúmeros, dentre eles, o medicinal. Desta heterogeneidade de populações, passa então, a existir um Conhecimento Tradicional, que se associa à Biodiversidade. Destarte, estas antigas comunidades cultivam uma lógica do funcionamento e do manejo dos recursos biológicos de sua fauna e flora e dos próprios processos biológicos.

Assim, a preocupação com o patenteamento dos produtos da floresta por multinacionais e com o repasse do conhecimento dos pajés sobre ervas medicinais é fato. Exemplifique-se com o emblemático caso da secreção do sapo (Phyllomedusa bicolor), chamado kambô para a etnia Katukina e kampô para a Yawanawa, tradicionalmente utilizada para afastar panema - azar na caça - e tirar sonolência ou mal-estar, quando há gripe ou estado febril. Tal secreção era um dos tratamentos para a malária (conhecida por sezão) e há notícias hoje de uma vacina largamente aplicada em São Paulo e Rio de Janeiro, sem qualquer retribuição lucrativa para as comunidades.

Acresce-se que os índios têm a legitimidade para tecer transações, cabendo a FUNAI sua responsabilidade como interveniente no processo. Afora as deficiências estruturais dos órgãos indigenista e ambiental do Estado brasileiro, em realidade, faz-se uma mercancia prejudicial aos índios carentes de bens de consumo.

\footnotetext{
5 SOS Mata Atlântica. Disponível em: <http://www.sosmatatlantica.org.br/index. php?section=info\&action=mata $>$. Acesso em: 18 jul. 2011.

6 FUNAI. Disponível em: <http://www.funai.gov.br>. Acesso em: 19 jul. 2011.
} 
Debate-se, ainda, a garantia aos povos interessados ao direito de obstaculizar terceiros não autorizados em divulgar ou repassar informações integrantes do conhecimento tradicional associado em consonância à Convenção da Organização Internacional do Trabalho - OIT n. 169 que reconhece o direito dos povos indígenas de viverem de acordo com as suas culturas.

E, em idêntica forma, controverte-se acerca da titularidade e da imprescritibilidade deste patrimônio cultural dinâmico, intergeracional e cujo nascimento no tempo é indefinido.

Intenta-se assim, neste ensejo, a defesa dos bens socioambientais intangíveis: conhecimentos, inovações e práticas dos povos indígenas, quilombolas e populações tradicionais associados ao seu aspecto econômico, podendo estes conhecimentos ser aproveitados imediata ou mediatamente num final acesso irregular ao patrimônio genético.

Enfim, indubitavelmente, toda esta soberana grandeza biológica e cultural implica cupidez, não apenas de indústrias madeireiras e colecionadores de animais, mas principalmente, de multinacionais farmacêuticas e de cosméticos, etc., travestindo atividades despidas de interesse financeiro em verdadeiras apropriações indevidas.

Os milhares de quilômetros de fronteira tornam extremamente dura a tarefa de conter o ingresso de biopiratas, num imenso vazio estatal. Mas, a Biodiversidade brasileira oferta inestimável potencial que pode ser convertido em investimentos, desenvolvimento tecnológico, produtos ambientalmente mais saudáveis e em melhor qualidade de vida, cabendo-lhe cuidados vários.

Não-obstante existam posturas de autoridade no sentido da negativa contribuição do Direito Penal para a tutela do meio ambiente, asseverando seu caráter meramente simbólico, que redunda na descarga do Poder Público em perseguir uma producente política de proteção ambiental ${ }^{7}$ experiências de países como Alemanha evidenciam que a guerra contra o ilícito ambiental é bem sucedida quando este igualmente apresenta a natureza de infração penal. ${ }^{8}$

\footnotetext{
7 "É minha opinião que não devemos continuar a insistir na mesma receita, ou seja, que não precisamos de more of the same, para utilizar uma expressão que é cara aos criminólogos ingleses. O Direito Penal, considerando o seu papel no tocante à política ambiental, tem-se revelado amplamente contraproducente. Se eu quisesse reformular esta mesma idéia de maneira ainda mais radical, então diria o seguinte: quanto mais direito penal do ambiente, menos proteção ambiental; quanto mais ampliarmos e agravarmos o direito penal do ambiente, tanto mais estaremos a dar maus passos, pois que, a persistir nessa senda, só viremos a produzir efeitos contrários aos pretendidos: ou seja, acabaremos contribuindo para uma inexorável diminuição da proteção efetiva do ambiente." (HASSEMER, Winfried. A preservação do ambiente através do direito penal. Revista Brasileira de Ciências Criminais, São Paulo, v. 22, p. 27-35, 2002, p. 28).

8 "Solo si la naturaleza delictiva de los daños al medio ambiente es caracterizada claramente mediante su integración en el Derecho penal y si se cuenta con sanciones que resultan imponentes frente al destructor del medio ambiente socialmente influyente y de cálculo racional, entonces se podrá abordar con cierto éxito la enorme tarea de la reestructuración ecológica de la sociedad industrial. En cambio, considero
} 
Demais, no Brasil, a subsidiariedade da Lei dos Crimes Ambientais, no trato da Biopirataria, não resolve, ${ }^{9}$ mesmo porque esta legislação é, por vezes, iníqua.

Não há distinção entre o usuário dos recursos naturais e o traficante ou mesmo o biopirata. E, nesta última hipótese, sequer alusão à Biopirataria strictu sensu.

Assim, explicita-se este característico perigo designado por Biopirataria, isto é, exploração e apropriação de recursos naturais e dos conhecimentos tradicionais associados, sem respeito às condicionantes de acesso, consentimento e por fim, repartição dos lucros revertidos, que atinge o Direito à Biodiversidade e o Direito à Sociodiversidade, na sua faceta seguinte, Conhecimentos Tradicionais associados.

Repise-se inda, a imprescindibilidade dos contornos legais, em todos os campos, mesmo em nível internacional, com instrumentos multilaterais, e com o fortalecimento de vínculos com outras nações megadiversas. Aliás, o abalançamento de soluções porventura adotadas por outras nações para o enfrentamento dessa problemática, a exemplo, Costa Rica, ${ }^{10}$ Equador, Peru, etc. é de suma valia.

ingenua la idea de poder iniciar un cambio de conciencia en toda la sociedad precisamente a través de la descriminalización." (SCHÜNEMANN, Bernd. ¿Ofrece la reforma del derecho penal económico alemán un modelo o un escarmiento? In: SCHÜNEMANN, Bernd. Obras. Buenos Aires: Rubinzal-Culzoni, 2009. t. 2. p. 218-242, p. 222).

9 "A conduta da biopirataria, seja com o simples acesso ou mesmo com a remessa ao exterior de material genético oriundo de nossa vida selvagem, hoje recebe acolhida no art. 29 da Lei n. 9.605/98, dispositivo que não atinge o dolo específico do biopirata, prevendo uma pena que apenas impõe ao transgressor algumas horas na delegacia, tempo suficiente para a lavratura de um simples termo circunstanciado, formalidade prevista para os casos de delitos de menor potencial ofensivo. Não há dessa forma, prisão em flagrante do infrator porque a biopirataria ainda é considerada um crime menor, de pequena monta.

O art. 29 da Lei n. 9.605/98, que trata da questão dos animais silvestres, foi concebido com o intuito de adequar condutas de criminosos que agem em desfavor da fauna tão somente apanhando, capturando, caçando, transportando, entre outras modalidades, com o fito de, no máximo, comercializar ou mercadejar com os animais, sem o caráter de prospecção de conhecimento e produção de riqueza. Não há uma previsão legal específica para aqueles que subtraem insumos da vida silvestre com fins industriais, de alto lucro." (COMISSÃO PARLAMENTAR DE INQUÉRITO DA BIOPIRATARIA. Audiência Pública, 10 nov. 2004. Com Jorge Barbosa Pontes Delegado da Polícia Federal e Chefe da Divisão de Repressão aos Crimes Ambientais da Polícia Federal).

10 "A lei costarriquenha prevê ainda um sistema de registro dos direitos intelectuais comunitários sui generis, e a realização de um inventário dos conhecimentos, inovações e práticas (relevantes para a conservação da biodiversidade) que as comunidades pretendam proteger, mantendo-se aberta a possibilidade de que, no futuro, sejam registrados e reconhecidos outros conhecimentos que reúnam as mesmas características. Tal registro é voluntário e gratuito, e deverá ser feito mediante solicitação dos interessados, sem qualquer formalidade. A existência de tal registro obrigará a Oficina Técnica de apoio à Comissão Nacional para Gestão da Biodiversidade a responder negativamente a qualquer consulta relativa ao reconhecimento de direitos de propriedade intelectual ou industrial sobre o mesmo recurso ou conhecimento. Tal resposta negativa, desde que devidamente fundamentada, poderá ocorrer mesmo quando o direito sui generis não esteja registrado." (SANTILLI, Juliana. Biodiversidade e conhecimentos tradicionais associados: novos avanços e impasses na criação de regimes legais de proteção. Revista de Direito Ambiental, São Paulo, v. 29 , n. 8, p. 83-102, mar. 2003 , p. 95 ). 
Além do mais, poder-se-ia cogitar do funcionamento de uma agência, a exemplo dos Estados Unidos (Law Enforcement), única para a matéria ambiental afinal, no Brasil o Poder Judiciário é pouco acionado à preservação de nossa fauna. Aliás, neste ínterim, convém um parêntese: fala-se, de fato, na necessidade de uma Agência Internacional de Meio Ambiente que juntamente a uma Corte Internacional de Meio Ambiente propiciem uma governança ambiental global.

Com proeminência, tem-se no âmbito internacional como basilar instrumento a ser aplicado quando da exploração da Diversidade Biológica e dos Conhecimentos Tradicionais associados, a Convenção das Nações Unidas sobre Diversidade Biológica. E sob seu feixe, em primeiro, as Diretrizes de Bonn sobre Acesso aos Recursos Genéticos e Participação Justa e Equitativa nos Benefícios Provenientes de sua Utilização, e, em segundo, o Protocolo de Nagoya sobre Acesso aos Recursos Genéticos e Participação Justa e Equitativa nos Benefícios que se Derivem de sua Utilização ao Convênio sobre a Diversidade Biológica.

Enfim, faz-se precisa uma legislação amplificada para barrar a Biopirataria, isto é, a criação de propriedade por meio da riqueza alheia.

Forçoso é vislumbrar então que, diversificadas proposituras legislativas estão em trâmite no Congresso Nacional dispondo-se a abolir a Biopirataria. Mister será alinhavar discussões, especificamente sobre o tipo penal de Biopirataria, contribuindo para o avanço do ordenamento jurídico hodierno brasileiro afinal, é clara a urgência no obstamento para os atentados cometidos contra a integridade de nossa Biodiversidade e contra o interesse estratégico do País de conservação e uso sustentável de nosso patrimônio genético. ${ }^{11}$

Rematando. A luta por uma normalização passa pelo debate sobre uma figura penal da Biopirataria, não se olvidando dos outros desafios: conservação e desenvolvimento sustentável, urgentes intervenções educacionais, socioeconômicas e fiscalizatórias, controle da má gestão pública e reforço de toda a legislação frente às questões inerentes ao acesso ao patrimônio genético e aos conhecimentos tradicionais associados e à repartição de benefícios.

11 Há discriminação nítida entre o tema da tese e a Lei da Biossegurança responsável pelo estabelecimento de normas de segurança e mecanismos de fiscalização no uso das técnicas de engenharia genética na construção, consumo, liberação e descarte ao meio ambiente de organismos geneticamente modificados (OGM), visando à proteção da vida e da saúde humana, dos animais, das plantas e da Terra. Noutras palavras, a fixação da biossegurança como conjunto de normas que tem por escopo reduzir ou evitar os riscos inerentes à manipulação genética. 


\section{Biopirataria}

\subsection{História}

Para alguns, a história da Biopirataria no Brasil teria surgido com sua própria descoberta, ${ }^{12}$ quando os portugueses granjearam o segredo da extração do pigmento vermelho do pau-brasil (Caesalpinia echinata), subtraindo conhecimentos tradicionais dos povos indígenas.

O labor dos índios, conhecedores do corante, foi empregado fortemente para cortar e triturar o tronco da árvore e assim, estabeleceu-se a concorrência com aquele corante que ia de Sumatra para as tecelagens do norte da Europa, e que era de melhor qualidade do que o corante brasileiro, mas muito mais caro. ${ }^{13}$

Outro exemplo simbólico da persistente prática é aquele referente à seringueira (nome binomial: Hevea brasiliensis), árvore nativa da Amazônia e aplicada na produção de borracha, alcançando posição de destaque dentro das atividades econômicas do País, entre o final do século XIX e o início do século XX. No fim daquele século porém, o botânico inglês Henry Alexander Wickham, a serviço do Império Britânico, transferiu setenta mil sementes de seringueira no vale do Tapajós, com a cooperação do cônsul inglês Thomas Shipton Green, residente em Belém, sendo o material enfim, levado para as colônias britânicas, África e Ásia, atualmente grandes produtores e fornecedores mundiais da matéria-prima. ${ }^{14}$

E, no panorama moderno, o rol exemplificativo da Biopirataria é extenso, ${ }^{15}$ podendo-se mencionar ainda, os episódios envolvendo a Castanha-do-pará, a Andiroba (amplamente usada na indústria cosmética e farmacêutica), a Ayahuasca (principal planta empregada nos rituais do Santo Daime), a Copaíba (de que se extrai o óleo), o Jaborandi (planta produtora de pilocarpina, empregada no combate ao glaucoma), o Curare, a Espinheira-Santa (de que se extrai o óleo), a Unha-de-gato, a Vacina do Sapo, dentre muitos outros planilhados.

12 GOMES, Rodrigo Carneiro. O controle e a repressão da biopirataria no Brasil. Revista do Tribunal Regional Federal da Primeira Região, ano 21, n. 2, p. 30, fev. 2009.

13 Segundo Nuno Pires de Carvalho, Em defesa da biodiversidade [Entrevista]. Revista Pesquisa FAPESP, ed. 84, p. 17-20, fev. 2003. Disponível em: $<$ http://revistapesquisa.fapesp.br/?art=2061\&bd=1\&pg=2\&lg=>. Acesso em: 23 jun. 2011.

14 ROCHA, Letícia Kolton. Um estudo crítico sobre a proteção dos conhecimentos tradicionais associados à biodiversidade. Revista Brasileira de Direito Ambiental, ano 6, v. 24, p. 109, out./dez. 2010.

15 Por Alfredo Kingo Oyama Homma, Extrativismo, biodiversidade e biopirataria na Amazônia. Brasília, DF: Embrapa Informação Tecnológica, 2008. p. 70. 
E, em cenário muito recente, em janeiro de 2003, a organização nãogovernamental Amazonlink descobriu o registro do cupuaçu pelos japoneses, originando intensa cobertura midiática.

Tudo iniciou em 1998, quando a multinacional japonesa Asahi Foods Co. Ltd. registrou perante os escritórios de patentes do Japão, dos Estados Unidos e da União Europeia, a marca comercial do Cupuaçu, para fins de comercialização e produção de uma espécie de chocolate dita "cupulate". Anos depois, a organização não governamental Amazonlink fora impedida de comercializar doces para a Alemanha porque ostentavam marca já protegida. Diz-se que: "Em outras palavras, a marca 'Cupuaçu' foi utilizada pela Asahi como uma patente de fato, a fim de impedir a entrada de concorrentes, produtores de alimentos derivados do cupuaçu, nos mercados onde a marca foi registrada". ${ }^{16}$

Em 2004, o Escritório de Marcas do Japão, restou por cancelar o registro como marca comercial do cupuaçu, solicitado pela multinacional japonesa Asahi Foods Co. Ltd., em virtude de demanda impetrada pelo Grupo de Trabalho Amazônico, Amazonlink, APA flora e outros. ${ }^{17}$ Aliás, convém ressaltar que, em realidade, já havia titularidade, desde a década de 1990, por empresa brasileira de pesquisa agropecuária - EMBRAPA - sobre o produto patenteado pela companhia asiática. ${ }^{18}$

Por consequência, o Brasil restou por redigir lista não exaustiva de nomes imbrincados à Biodiversidade ${ }^{19}$ e remeter a Organização Mundial da Propriedade Intelectual numa tentativa de refrear próximas condutas expropriatórias e prioritariamente, como maneira de robustecer prova reivindicatória futura em demandas altamente custosas. Lembrando que, faz parte da responsabilidade intergeracional na preservação de tal patrimônio.

E aliás, por obviedade, a Biopirataria atinge outras Nações. Conforme levantamento da $\mathrm{RAFI}^{20}$ na América, poder-se-ia citar ainda Direitos de Propriedade Intelectual sobre algodão naturalmente colorido originário dos Andes, quinua andina, o feijão "nuna", também herança andina. ${ }^{21}$

16 RODRIGUES JÚNIOR, Edson Beas. Tutela Jurídica dos recursos da biodiversidade, dos conhecimentos tradicionais e do folclore: uma abordagem de desenvolvimento sustentável. Rio de Janeiro: Elsevier, 2010. p. 13-15.

17 HOMMA, Alfredo Kingo Oyama. Extrativismo, biodiversidade e biopirataria na Amazônia. Brasília, DF: Embrapa Informação Tecnológica, 2008, p. 69.

18 HERINGER, Astrid. Os conhecimentos tradicionais associados e o acesso aos recursos genéticos: um estudo sobre a regulamentação da medida provisória n. 2.186-16/01. Revista Amazônia Legal de Estudos Sócio-Jurídico-Ambientais, Cuiabá, ano 1, n. 2, p. 131-148, jul./dez. 2007, p. 139.

19 CF. arts. $7^{\circ}$ e $9^{\circ}$ da CDB.

20 Rural Advancement Foundation International, chamada atualmente de ETC-Group (Action Group on Erosion, Technology and Concentration).

21 CABRERA MEDAGLIA, José Alberto. Bioderecho: propiedad intelectual, comercio y ambiente. San José, C.R.: EUNED, 2011. p. 100. 


\subsection{Biopirataria}

Importa realçar que, o vocábulo Biopirataria não encontra assento na legislação brasileira, nem mesmo em qualquer instrumento jurídico internacional. ${ }^{22}$ Trata-se, em verdade, de conceito doutrinário referente à apropriação não autorizada do patrimônio genético, como também, dos conhecimentos tradicionais associados à biodiversidade.

Empregado pela primeira vez, no ano de 1993, por uma organização não governamental canadense, denominada RAFI (Rural Advancement Foundation International), hoje chamada de ETC-Group (Action Group on Erosion, Technology and Concentration), denotava a exploração e, ulterior patenteamento, de recursos biológicos e processos derivados de conhecimentos tradicionais associados de outros países por multinacionais ou mesmo, instituições de pesquisa, ${ }^{23}$ engendrando consequências graves, dentre elas, a não repartição dos lucros revertidos com o comércio de produtos originados a partir de seus tirocínios e a impossibilidade, numa derradeira instância, por causa das patentes, das próprias comunidades tradicionais em usar seus conhecimentos gerados. ${ }^{24 / 25}$

22 Segundo Nuno Pires de Carvalho, à época, Chefe da Seção de Recursos Genéticos, Biotecnologia e Conhecimentos Tradicionais Associados da Organização Mundial de Propriedade Intelectual (OMPI) em entrevista intitulada "Em defesa da biodiversidade" (Revista Pesquisa FAPESP, ed. 84, fev. 2003. Disponível em: $<\mathrm{http}: / /$ revistapesquisa.fapesp.br/?art=2061\&bd=1\&pg=2\&lg=>. Acesso em: 23 jun. 2011), a OMPI estaria substituindo o termo Biopirataria por Biogrilagem, primordialmente porque, na falta de uma legislação de acesso, não haveria ilegalidade na exploração dos recursos genéticos. Inda, mesmo com a citada legislação, a ilegalidade dar-se-ia apenas no país da coleta desaprovada e não no país da patente do bioproduto. Por fim, a palavra pirataria, desde o advento do Acordo Trips, aplicar-se-ia para denominar alguns tipos de infração dos direitos de autor, não incluindo marcas e patentes. Assim: "sugerese que a qualificação mais apropriada para esses atos seria a de biosquatting, que poderia ser traduzida por biogrilagem. Squatting significa a reivindicação privada de terras que pertencem a outrem ou que são de domínio público. Também designa simplesmente 'invasão' ou 'ocupação' de propriedade imóvel e não são necessariamente ilegais, pois pode haver lacunas na lei que acabam por 'legitimar' a ocupação privada de terras públicas."

23 Sob a figura de convênios de cooperação científica, laboratórios de institutos e universidades amazônicas eram visados na década de 90 pelos Biopiratas, que conseguiam assim, plantas e animais para fins de emprego na indústria farmacêutica, têxtil, cosmética e alimentícia, inclusive a partir de pesquisadores brasileiros ingênuos. OTÁVIO, Chico. Inventário Amazônia: ocupação, preservação e futuro. Rio de Janeiro: Desiderata, 2007. p. 117.

24 WANDSCHEER, Clarissa Bueno. Reflexões sobre a Biopirataria, Biodiversidade e Sustentabilidade. In: SILVA, Letícia Borges da; OLIVEIRA, Paulo Celso de (Org.). Socioambientalismo: uma realidade: Homenagem a Carlos Frederico Marés de Souza Filho. Curitiba: Juruá, 2007. p. 68.

25 Cf. CABRERA MEDAGLIA, José Alberto. Bioderecho: propiedad intelectual, comercio y ambiente. San José, C.R.: EUNED, 2011. p. 99: "Cabe, además, citar la preocupación de quienes consideran que en aquellos casos en los cuales las patentes cubran un componente activo de una planta específica, la cual es utilizada tradicionalmente por comunidades locales o indígenas, el efecto de la protección por la patente podría restringir las posibilidades de los pueblos indígenas o comunidades locales de exportar la planta tal cual al país que la proteja, aún si se realiza para un uso medicinal diferente o incluso para un uso no relacionado. Este tópico cobra especial relevancia ante las denuncias de que el sistema de patentes constituye un mecanismo de apropiación de conocimiento tradicional y de recursos genéticos sin una justa 
Cuida-se, portanto, de um exercício ilícito de evasão de material biológico e/ou microbiológico para o exterior, com posterior incorporação de tecnologia, transformando tal material em inovação tecnológica e, por conseguinte, patenteando seja o próprio processo seja o produto.

Tais métodos ilegais incidem de maneira assemelhada sobre os conhecimentos tradicionais. Os Biopiratas entram em contato com as antigas comunidades, sob o manto de estudiosos ou mesmo religiosos, e apropriam-se das práticas milenarmente consagradas por estas populações. ${ }^{26}$

Perceba-se, por outro lado que, todos os vieses da Biopirataria se intercalam.

Assim também, o tráfico de fauna que além de pernicioso por si só, viabilizando, por óbvio, um prejuízo ao meio ambiente como um todo, mais ainda, vinculase a à Biopirataria stricto sensu, a partir do instante em que, os animais encontram-se no exterior, sendo criados e reproduzidos com feliz resultado, e a indústria tem acesso a um novo modelo experimental ou a uma original fonte de princípios ativos. $\mathrm{O}$ combate ao tráfico de animais silvestres, por puro diletantismo contudo, tem encerramento mais simples que aquele relacionado à Biopirataria em sentido estrito: as rotas são conhecidas e desta maneira, facilmente cobertas e vigiadas.

Mas indispensável inda, é uma legislação rigorosa afinal, a Lei n. 9.605/98 não se entremostra profícua, diante de traficantes de espécies altamente rentáveis se colocadas nos mercados europeu, americano ou asiático. O tráfico de animais silvestres movimenta entre 10 e 20 bilhões de dólares no mundo, conservando o terceiro posto de tráfico mais lucrativo do mundo (sendo os Estados Unidos, Alemanha, França, Inglaterra, Suíça, Arábia Saudita e Japão os maiores consumidores), atrás pois, do tráfico de entorpecentes e de armas. ${ }^{27}$ Calcula-se que aproximadamente trinta e oito milhões de animais sejam traficados no Brasil representando algo em torno de um bilhão e meio de dólares; de cada dez animais traficados, nove morrem durante a coleta ou o transporte, tendo em vista inclusive o desequilíbrio que a retirada dos espécimes de seu meio acarreta na cadeia biológica e também, a considerada baixa sobrevida em razão de maus-tratos, erros de manejo e inadequação da alimentação depois que os animais chegam ao destino,

y equitativa distribución de beneficios, e incluso sin el consentimiento fundamentado previo de éstos y Del Estado de onde provienen los recursos": (g.n.).

26 DEL NERO, Patrícia Aurélia. Humanismo latino: o Estado brasileiro e as patentes biotecnológicas. In: MEZZAROBA, Orides. Humanismo latino e Estado no Brasil. Florianópolis: Fundação Boiteux; Treviso: Fondazione Cassamarca, 2003. p. 305.

27 Essa modalidade de ilicitude movimenta aproximadamente US\$ 10 bilhões anualmente em todo o planeta, sendo o Brasil responsável por aproximadamente US\$ 1 bilhão ao ano, de acordo com levantamento proveniente do IBAMA. Disponível em: $<$ http://www.camara.gov.br/proposicoesWeb/prop_mostrarintegr a?codteor $=982124 \&$ filename $=P L+3710 / 2012>$. Acesso em: 01 out. 2102. 
com dano de monta ao patrimônio faunístico. ${ }^{28}$ A lista brasileira da fauna ameaçada de extinção, publicada desde 1973, vem crescendo, sendo que a última revisão, elenca trezentos gêneros ameaçados. ${ }^{29}$ Diante disso, o tráfico de animais silvestres é tido como a segunda maior causa de extinção de espécies, perdendo unicamente para a supressão de hábitat. Aliás, no caso da Lei dos Crimes Ambientais (LCA), perceba-se que estão também, no mesmo tipo penal, infrações praticadas contra espécies ameaçadas de extinção e espécies que não estão ameaçadas. Logo, o tráfico de animais segue infinitamente vantajoso $^{30}$ porque a sanção é diminuta, inviabilizando assim, por exemplo, o início do resgate em regime fechado, mesmo porque, é costumeiramente substituída. Destarte, o poder de dissuasão necessita ser altíssimo, mormente em confronto ao atual quadro em que, mesmo alguns crimes da Lei n. 9.605/98, que acertam a sociedade de forma mais grave, estão sob a incidência da Lei n. 9.099/95.

No que tange ainda à flora, vale apontar que, incontáveis plantas hoje em dia empregadas na farmacologia indígena são conhecidas dos laboratórios da Europa, podendo ser patenteadas porque o Tribunal de Patentes Internacional é absolutamente irresponsável com relação a essa nuance, como no caso do cupuaçu, cuja marca foi anulada pelo Brasil após longa luta.

Inexecutável se estimar o quantum o Brasil é despojado com a Biopirataria, principalmente tendo por base a distribuição de benefícios não feita e o vácuo de oportunidades ligadas ao mercado de medicamentos. ${ }^{31}$ Aqui, a Biopirataria é patrocinada pela globalização que multiplica as chances de registro de patentes em âmbito internacional. A proteção da Biodiversidade é emergencial tendo em consideração inclusive informes no sentido de que a quase totalidade de investimentos na indústria farmacêutica concentra-se

28 REDE NACIONAL DE COMBATE AO TRÁFICO DE ANIMAIS SILVESTRES (RENCTAS). Disponível em: <http://vww.renctas.com.br.htm>. Acesso em: 26 out. 2007.

29 IBAMA. Anexo à Instrução Normativa n. 3, de 27 de maio de 2003, do Ministério do Meio Ambiente. Lista das Espécies da Fauna Brasileira Ameaçadas de Extinção. Disponível em: <http://www.ibama.gov.br/fauna/ downloads/lista\%20spp.pdf>. Acesso em: 18 jul. 2011.

30 Convém neste ínterim, um pequeno parêntese no que pertence aos Termos de Ajustamento de Conduta (TAC). São instrumentos pelos quais os órgãos públicos legitimados para a propositura da ação civil pública celebram acordo com autor do dano visando total reparação do status quo ante o evento danoso, ou sua prevenção, por meio de obrigações de fazer, não fazer ou de dar coisa certa, pena da impingência de preceitos cominatórios, ou da imposição de outras obrigações. Sublinhe-se, que o mérito do TAC é sua possibilidade de maior flexibilização em termos de modo, prazo e lugar de cumprimento da obrigação de reparar e prevenir o dano previsto. Nasceu para prevenir e reparar prejuízos, atuando na seara da responsabilidade civil, obstando pois, o ajuizamento de ações coletivas, sem repercussão na responsabilidade administrativa e penal já incidentes quando da perpetração de ilícitos ambientais. Há ataques porém, quanto ao seu emprego que afronta sua concepção como instituto, redundando em fraudes à legislação ambiental ao dar, ao cabo, desconto substancial em prévias multas administrativas.

31 Cf. COMISSÃO PARLAMENTAR DE INQUÉRITO DA BIOPIRATARIA. Audiência Pública, 17 nov. 2004. Com João Paulo Ribeiro Capobianco. Secretário de Biodiversidade e Florestas do Ministério do Meio Ambiente (MMA). 
em poucos ricos países com matéria-prima entretanto formada predominantemente por recursos genéticos obtidos no Brasil, leia-se, Amazônia legal. ${ }^{32}$

O Instituto Brasileiro do Meio Ambiente e dos Recursos Naturais Renováveis (IBAMA) é legalmente responsável pela gestão do uso de quaisquer espécies com viabilidade econômica. Sobretudo no que tange à Biopirataria stricto sensu, foi criada no IBAMA a Divisão de Controle da Fiscalização e Acesso ao Patrimônio Genético, pretendendo que o desenvolvimento biotecnológico reverta em prol das populações tradicionais e indígenas, bem como, mui recentemente, seção especialmente voltada ao combate da Biopirataria. Há por outro lado, a Divisão de Propriedade Intelectual no Ministério das Relações Exteriores, que atua diretamente junto aos demais governos e empresas que patentearam produtos, tecendo contatos, contratando advogados, numa tentativa de repatriar tais direitos. Vale realçar, o trabalho do Conselho Nacional de Desenvolvimento Científico e Tecnológico (CNPq) que em hipótese de remessa de material para o exterior, impõe aos dirigentes das instituições brasileiras e estrangeiras e as contrapartes brasileira e estrangeira firmarem "Termo de Compromisso: Exclusividade e Patente", comprometendo-se a usar as amostras exclusivamente com finalidade de estudo, pesquisa e difusão e repartirem, igualmente, entre as partes envolvidas, eventuais benefícios que possam redundar em novos produtos. Ademais, se a consultoria científica do CNPq considerar que a pesquisa impulsionará posterior bioprospecção, o projeto será enviado ao Conselho de Gestão do Patrimônio Genético (CGEN) para a obtenção da respectiva autorização.

As providências contudo, ainda são insuficientes e interessa apontar todavia, a resistência dos países mais desenvolvidos, em todos os sentidos, que seguramente ditam as pesquisas e o patenteamento mundiais, obedientes ao princípio do TRIPS (que não obriga a identificação do País de origem da matéria-prima). Nada obstante existam severas críticas à lenta tramitação do credenciamento de pesquisadores e suas perguntas científicas, em vista da certeza de que os organismos, os animais e as plantas não conhecem fronteiras, com risco pois, de uma debandada de sérios cientistas para outros países, imperiosa a mantença de controle com a devida agilização. ${ }^{33}$

32 Disponível em: < http://www.comciencia.br/reportagens/biodiversidade/bio05.htm>. Acesso em: 28 jan. 2012.

33 Verificação das Leis Estaduais do Acre (Lei n. 1.235/97) e do Amapá (Lei n. 388/97) que regulam a coleta de material científico por estrangeiros. A lei acreana teria como antecedente prática de biopirataria: "A Selva Viva (ONG) contava com o apoio das multinacionais farmacêuticas Ciba Geigy, Hoescht, Sandoz, Lilly, Jhonson \& Jhonson para estimular os índios a catalogar e produzir viveiros de plantas medicinais existentes em comunidades indígenas no Acre. Em troca desse trabalho, a entidade doava remédios e prometia ajuda financeira para projetos de auto-sustentação." (FIORILLO, Celso Antonio Pacheco; DIAFÉRIA, Adriana. Biodiversidade e patrimônio genético no direito ambiental brasileiro. São Paulo: Max Limonad, 1999, p. 23). 
Conforme o Instituto Brasileiro de Direito do Comércio Internacional, da Tecnologia da Informação e Desenvolvimento ${ }^{34}$ (CIITED), Biopirataria consiste no "ato de aceder a ou transferir recurso genético (animal ou vegetal) e/ou conhecimento tradicional associado à biodiversidade, sem a expressa autorização do Estado de onde fora extraído o recurso ou da comunidade tradicional que desenvolveu e manteve determinado conhecimento ao longo dos tempos", procedimento este que transgride os arranjos vinculantes da Convenção das Organizações Unidas sobre Diversidade Biológica. A Biopirataria compreende ainda, a "não-repartição justa e equitativa - entre Estados, corporações e comunidades tradicionais dos recursos advindos da exploração comercial ou-não dos recursos e conhecimentos transferidos".

Biopirataria é portanto, em última instância, a utilização da propriedade intelectual sobre a Biosociodiversidade em desobediência aos requisitos prescritos pela Convenção de Diversidade Biológica, quais sejam, preservação da Biodiversidade, respeito à Soberania do país sobre seus recursos naturais, implemento da legislação de acesso do país de origem, inclusive com consentimento prévio e informado, proteção dos direitos das comunidades autóctones, repartição de benefícios, inclusive com transferência de tecnologia.

Mister, neste ínterim, pontuar que nada obstante a concepção até este presente instante assumida - acesso irregular ao Patrimônio Genético - não se pode olvidar que existem sim, outras definições com outros enfoques. Veja:

Biopiratería: no existe una definición internacionalmente acordada del término. Para algunos consiste en la adquisición de recursos genéticos y conocimiento tradicional sin el permiso del país o titular del recurso o conocimiento; es decir, cuando no se establecen reglas de distribución de beneficios que sean justas y equitativas, se protegen por DPI (Derechos de Propiedad Intelectual) innovaciones, que son copias o modificaciones cosméticas de los primeros o se protegen por DPI (Derechos de Propiedad Intelectual) invenciones biotecnológicas, independientemente de la existencia de consentimiento fundamentado previo. ${ }^{35}$ (g.n.)

Em nosso país, a Biopirataria faz-se presente sobretudo em virtude da já aludida megadiversidade biológica e social, da enorme extensão territorial que impede efetiva fiscalização, da falta de investimentos nas áreas de ciência e tecnologia, ${ }^{36}$

34 AMBIENTE Brasil. Biopirataria na Amazônia. Disponível em: < http://ambientes.ambientebrasil.com.br/ amazonia/floresta_amazonica/biopirataria_na_amazonia.html>. Acesso em: 28 out. 2011.

35 CABRERA MEDAGLIA, José Alberto. Bioderecho: propiedad intelectual, comercio y ambiente. San José, C.R.: EUNED, 2011. p. 3.

36 GRIMALDI, Karina. Tutela jurídica administrativa da biodiversidade de fauna silvestre brasileira e o 
tornando-se deste modo, altamente exposto nesta conjuntura de avanços das demandas biotecnológicas.

Destarte, o mote é complexo e delicadíssimo, pois envolve tanto os recursos sobre as quais os Estados exercem sua soberania, como os contingentes populacionais implicados.

E neste ínterim, não se pode olvidar que a Soberania é um dos fundamentos da República Federativa do Brasil, segundo disposto no inciso I do art. $1^{\circ}$ da Constituição da República.

Aliás, importa salientar que a citada Convenção da Diversidade Biológica representou um marco à medida que pontuou como princípio em seu art. $3^{\circ}$ para os Estados - o direito soberano de explorar seus próprios recursos segundo suas políticas ambientais -, observada a correlativa responsabilidade ambiental, abandonando a concepção prévia de bens ambientais como patrimônio comum da humanidade, ${ }^{37}$ o que propiciava o acesso direto, por quaisquer exploradores, a estes recursos dispensada algum tipo de autorização do país de origem. Noutros termos, a citada Convenção sobre Diversidade Biológica referenda o primordial aspecto que funda toda esta discussão, qual seja, a Soberania dos países sobre seus recursos naturais, leia-se, sobre seu Patrimônio Genético, ${ }^{38}$ ao reverso do que antes regia - Biodiversidade como Patrimônio Comum da Humanidade - e por consequência, a indispensabilidade de uma distribuição justa e equitativa de benefícios resultantes do uso destes recursos, que por sua vez, dentre uma série de requisitos deve sim, ser facilitado.

Assim sendo, pretende-se, em verdade, obstaculizar a consumação de um - bioimperialismo-, isto é, o vetusto abuso dos recursos naturais dos países em desenvolvimento pelos países ricos (agora detentores da biotecnologia), sob um novo paradigma, qual seja, o patenteamento de bioprodutos a partir do patrimônio genético e, por sua vez, dos conhecimentos tradicionais associados, em acesso ou uso ou aproveitamento ilegal, irregular ou não equitativo. ${ }^{39}$

combate à biopirataria. Revista Brasileira de Direito Ambiental, ano 6, v. 14, p. 176, abr.jun. 2008.

37 Id. Ibid., p. 169.

38 Vale salientar que existe alargamento desta visão acerca de Soberania sobre Patrimônio Genético. Veja neste sentido, o REGIMEN COMUN DE ACCESSO A LOS RECURSOS GENETICOS DECISION 391 DE LOS PAISES DEL PACTO ANDINO. (...) TITULO IV PRINCIPIOS CAPITULO I De la soberanía sobre los recursos genéticos y sus productos derivados. (g.n.).

39 Biopirataria não se confunde com Bioprospecção, conceituada esta como "o método ou forma de localizar, avaliar e explorar sistemática e legalmente a diversidade de vida existente em determinado local, tendo como objetivo principal a busca de recursos genéticos e bioquímicos para fins comerciais" (HERINGER, Astrid. op. cit., p. 135) ou "atividade exploratória que visa identificar componente do patrimônio genético e informação sobre conhecimento tradicional associado, com potencial de uso comercial" (art. $7^{\circ}$, inciso VII da Medida Provisória n. 2.186-16/2001). 
Destarte, os Direitos de Propriedade Intelectual vislumbrados como meio de privatização, de fato, não confrontam, ao final, com tal ideia de Soberania, eis que sujeitos a inúmeros condicionamentos, chegando mesmo à sua proibição, para o que nos interessa, ad exemplum, se prejudiciais ao ambiente. ${ }^{40}$

Em verdade, o que se deve perceber é que, nos últimos tempos, qualquer informação, seja advinda do Patrimônio Genético, seja advinda do conhecimento tradicional associado, floresceu como maior fator de produção - commodity - aliás numa sequencia de agigantamento do Direito de Propriedade Intelectual. ${ }^{41}$ Noutras palavras, a pesquisa sobre os Recursos Genéticos pode redundar em novedosos conhecimentos ou mesmo em royalties e porquanto, dever-se-á ter um compartilhamento entre quem forneceu os recursos e quem os processou, estes resguardados pelas Patentes. ${ }^{42}$

Abrindo um parêntese, importa destacar a infindável controvérsia sobre o valor Vida, diante do esgotamento da Biodiversidade e das polêmicas suscitadas pela biotecnologia. Noutros termos, aflora uma ética biocêntrica que alude que seja considerado o valor inerente à vida de cada indivíduo, refutando-se a hipótese de que interesses comerciais, estéticos, científicos, etc. possam prestar-se como manto absoluto para descartes de vidas, tanto valendo para humanos, animais não humanos e ecossistemas naturais. Em verdade, parece haver um denominador comum contudo, isto é, o Princípio do Menor Custo Moral. ${ }^{43}$

40 ACORDO SOBREASPECTOS DOS DIREITOS DE PROPRIEDADE INTELECTUALRELACIONADOS AO COMÉRCIO.

(...)

SEÇÃO 5: PATENTES

ARTIGO 27 Matéria Patenteável. (...)

2. Os Membros podem considerar como não patenteáveis invenções cuja exploração em seu território seja necessário evitar para proteger a ordem pública ou a moralidade, inclusive para proteger a vida ou a saúde humana, animal ou vegetal ou para evitar sérios prejuízos ao meio ambiente, desde que esta determinação não seja feita apenas por que a exploração é proibida por sua legislação.

3. Os Membros também podem considerar como não patenteáveis: (...)

b) plantas e animais, exceto microorganismos e processos essencialmente biológicos para a produção de plantas ou animais, excetuando-se os processos não-biológicos e microbiológicos. Não obstante, os Membros concederão proteção a variedades vegetais, seja por meio de patentes, seja por meio de um sistema sui generis eficaz, seja por uma combinação de ambos. O disposto neste subparágrafo será revisto quatro anos após a entrada em vigor do Acordo Constitutivo da OMC. (g.n.).

${ }^{41}$ RODRIGUES JÚNIOR, Edson Beas. ob. cit.., p. 2.

42 Cf. CABRERA MEDAGLIA, José Alberto em BIOPIRATERÍA EN AMERICA LATINA: DESAFIOS Y RESPUESTAS LEGALES E INSTITUCIONALES. Artigo ainda não publicado gentilmente cedido pelo próprio autor em mãos.

43 Cf. questão da patenteabilidade de partes ou do todo de seres não-humanos, da "eugenia liberal" e dos xenotransplantes. Quanto a este último aspecto: "Lo que está claro, sin embargo, es que incluso si uno considera estas prácticas admisibles, el sacrificio de otros animales que las mismas implican debería dar lugar a un arrepentimiento moral, dado su valor. El coste ético de estos procedimientos no ha de olvidarse. Ello conduce a considerar que existen alternativas y medios con un menor coste moral para llegar las mismas metas en estos casos, deberíamos adoptarlos, incluso quizás si ello conlleva una menor efectividad. Esta 
Sobre esta novel ética ambiental, ilustra Eduardo Ramalho Rabenhorst:

Afinal, mesmo que toda atitude valorativa seja humana, o homem pode atribuir à natureza um valor que não seja auto-referencial, isto é, um valor que não traduza apenas os interesses humanos (como bem reconhece a Convenção sobre a diversidade biológica, todo ser vivo, pelo simples fato de existir e desenvolver estratégias complexas para conservar a vida e reproduzir-se, tem um valor inerente, independente do que possa proporcionar à espécie humana. ${ }^{44}$

Parece exato que, ao final, não se pode prescindir do respeito aos homens e à Natureza. Noutras palavras, indispensável uma revisitação à concepção de comunidade, agora com uma polis planetária em congraçamento constante de homens entre homens e de homens com a Natureza, incompatível com um rígido conservacionismo, incapaz de lograr alternativas. Se todos arcarão com os prejuízos ambientais, na sociedade pósmoderna, recorde-se, globalizada, a normatividade postula o direito de deliberação advindo da completude social, e primordialmente, com direito à adoção das medidas que apresentem o menor custo moral para esta mesma comunidade.

Voltando. Não se pode olvidar que, esta hipertrofia protetora dos inventores confronta com uma real defesa da Biosociodiversidade, principalmente no que concerne à prévia repressão aos atos de apropriação indébita sucedidos nos países ditos provedores. Assim, a preocupação dá-se, nos países industrializados, já num momento posterior àqueloutro expropriatório, e igualmente, envolvendo diferentes atores. Aliás, em propositada irresponsabilidade no que concerne às medidas protetivas enquanto países

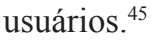

E depreende-se afinal que:

A visão estreita de curto prazo dos regimes de Propriedade Intelectual ignora as conseqüências nefastas que advirão,

es una importante consideración en el caso de xenoinjertos donde existen fuentes alternativas de órganos... el xenoinjerto únicamente resulta aceptable desde el punto de vista ético si hemos llegado a la conclusión de que nada más se puede hacer para incrementar la cantidad de órganos disponibles por otras vías, que impliquen un menor coste moral." (ENGELS, Eve-Marie. El estatuto moral de los animales en la discusión sobre el xenotrasplante. In: ROMEO CASABONA, Carlos et al. Los xenotrasplantes: aspectos científicos, éticos y jurídicos. Granada: Comares, 2002, p. 322).

44 RABENHORST, Eduardo Ramalho. O valor do homem e o valor da natureza. Breve reflexão sobre a titularidade dos direitos morais. In: SILVEIRA, Rosa Maria Godoy et al. (Orgs.). Educação em direitos humanos: fundamentos teórico-metodológicos. João Pessoa: Juruá, 2007. p. 227.

45 Cf. entretanto, recomendação em Diretrizes de Bonn sobre Acesso aos Recursos Genéticos e Participação Justa e Equitativa nos Benefícios Provenientes de sua Utilização: "Medidas para promover a revelação do país de origem dos recursos genéticos e de origem dos conhecimentos, inovações e práticas tradicionais das comunidades indígenas e locais em aplicações de Direitos de Propriedade Intelectual" (16.d.ii). Aqui ainda, vale um parêntese quanto ao diferenciado tratamento para a inobservância dos ditames para patenteamento, isto é, afetação ou não da própria validade da patente. 
inclusive, aos países industrializados e suas instituições. No longo prazo, se as comunidades tradicionais continuarem a ser sistematicamente espoliadas, é possível que, em meio à miséria material em que muitas delas vivem, venham a perecer e com elas seu Patrimônio Biocultural Imaterial e biomas a ele relacionados. Neste contexto, os Direitos de Propriedade Intelectual representam uma ferramenta biocolonial, ao promover crescimento econômico selvagem, marcado pela busca incessante do lucro pelos grandes conglomerados e instituições dos países industrializados às expensas dos grupos marginalizados e da natureza. ${ }^{46}$

Importa reiterar no que tange ao tudo que já fora dito sobre Biopirataria que se tem como inegável um imbricamento entre Direitos de Propriedade Intelectual e Biodiversidade. E, tal impactação transcende o que já fora disposto entre Direitos de Propriedade Intelectual e Convenção sobre Diversidade Biológica e seus principais objetivos. Por exemplo, os impactos dos Direitos de Propriedade Intelectual sobre a Biodiversidade atingem inclusive sua interface de permuta de benefícios, ao se pensar em transferência de tecnologia energeticamente eficaz ou numa agregação de valor a todos os produtos por conta da incorporação verde. ${ }^{47}$

Contudo, também no que concerne ao compartilhamento de benefícios, ausente uma severa política para tanto. ${ }^{48}$

Neste ínterim, alerta-se para a força dos países megadiversos em compelir os países desenvolvidos a um maior respeito aos ditames da $\mathrm{CDB}$ e à proteção da Biosociodiversidade. ${ }^{49}$

46 RODRIGUES JÚNIOR, Edson Beas. Tutela Jurídica dos recursos da biodiversidade, dos conhecimentos tradicionais e do folclore: uma abordagem de desenvolvimento sustentável. Rio de Janeiro: Elsevier, 2010. p. 79 .

47 CABRERA MEDAGLIA, José Alberto. Bioderecho: propiedad intelectual, comercio y ambiente. San José, C.R.: EUNED, 2011. p. 2 e 111.

48 Cf. entretanto, recomendação em PROTOCOLO DE NAGOIA NO ÂMBITO DA CONVENÇÃO DA DIVERSIDADE BIOLÓGICASOBRE ACESSO A RECURSOS GENÉTICOS E A REPARTIÇÃO JUSTA E EQUITATIVA DOS BENEFÍCIOS DECORRENTES DE SUA UTILIZAÇÃO: "Cada Parte tomará as medidas legislativas, administrativas e de política, conforme adequado, para que os benefícios decorrentes da utilização do conhecimento tradicional associado a recursos genéticos sejam repartidos de forma justa e equitativa com as comunidades indígenas e locais detentoras desse conhecimento. Essa repartição deve se dar em termos mutuamente acordados." (Artigo $5^{\circ} .5$ ).

49 Cf. CABRERA MEDAGLIA, José Alberto em BIOPIRATERÍA EN AMERICA LATINA: DESAFIOS Y RESPUESTAS LEGALES E INSTITUCIONALES. Artigo ainda não publicado gentilmente cedido pelo próprio autor em mãos:

“(...) en enero del 2002, se formó en México el Grupo de Países Megadiversos Afines o GAPMA (creado mediante la Declaración de Cancún).

A iniciativa del gobierno de México, los ministros y altos funcionarios de los países megadiversos de Brasil, China, Colombia, Costa Rica, Ecuador, India, Indonesia, Kenia, México, Sudáfrica y Venezuela, se reunieron la ciudad de Cancún de 16 al 18 de febrero del 2002 y decidieron establecer el GAPMA. Posteriormente, 
Repise-se, a proteção da Biosociodiversidade justifica-se ilimitadamente.

A defesa do Patrimônio Genético, inclusive para fins de criação de novas variedades em contraste a uma ameaçadora erosão genética estimulada pelo patenteamento de variedades homogêneas, por exemplo, nos sistemas de monocultivo, alerta para a gravidade do problema. ${ }^{50}$

Ainda, cogente fazer mais referência a outro aspecto deste assunto, qual seja, o prejuízo financeiro desta prática para o país.

O combate à Biopirataria assegura, além da garantia do equilíbrio ecológico do meio ambiente, bem assim, o desenvolvimento nacional, um dos objetivos da República inserido no inciso II, do art. $3^{\circ}$ da Constituição do Brasil, diante do inestimável potencial econômico compreendido na concepção de Biodiversidade e Conhecimentos Tradicionais associados. $^{51}$

Por derradeiro, tem-se que anotar que, à expressão desenvolvimento nacional, hodiernamente agrega-se o predicado sustentável, à medida que se percebe a urgente obrigação da atividade econômica respeitar a noção de finitude dos recursos naturais, conformando-se a um uso racional, equilibrado, planificado e assim, sustentável. ${ }^{52}$

Uma observação faz-se de relevo entretanto.

$\mathrm{Na}$ realidade, pode-se ter a expressão - desenvolvimento sustentável como de forte incoerência, à medida que, de maneira singela, é certa a destruição do Planeta se bilhões de seres humanos principiarem a consumir. Assim, nada obstante se tratar de fórmula já muitíssimo consagrada, há de ver-se que, de fato, a sustentabilidade a ser perseguida e prioritária é aquela que diz respeito à vida do ecossistema na Terra, e não do desenvolvimento. ${ }^{53 / 54}$

suscribieron la Declaración de Cancún y fueron aceptados formalmente en el Grupo de Acción, Bolivia, Malasia y Filipinas.

En su conjunto, el Grupo de Acción de Países Megadiversos Afines representa aproximadamente el 70\% de la diversidad biológica del planeta, cerca de $45 \%$ de la población mundial, así como una extraordinária diversidad cultural." (g.n.).

50 CABRERA MEDAGLIA, José Alberto. Bioderecho: propiedad intelectual, comercio y ambiente. San José, C.R.: EUNED, 2011. p. 107.

${ }^{51}$ GRIMALDI, Karina. op. cit.

52 A ordem econômica, cuja finalidade expressa na Carta Suprema é "assegurar a todos existência digna, tem como um de seus princípios a "defesa do meio ambiente". Conferir art. 170 da Constituição Federal.

53 POSTIGLIONE, Amedeo. Global Environmental Governance: The need for an International Environmental Agency and an International Court of the Environment. Bruxelas, Etablissements Emile Bruylant, S.A.A., 2010, p. 3-7.

54 Cf. POSTIGLIONE, Amedeo. op.cit., p. 77: "The relation between environmental protection and human rights was explicitly recognized for the first time in Stockholm in 1972: it is significant that the object of the Conference was 'the human environmental' and that Principle No. 1 proclaimed that 'Man has the fundamental right to freedom, equality and adequate conditions of life, in an environment of a quality that permits a life of dignity and well-being, and he bears a solemn responsibility to protect and improve the environment for the present and future generations'. In the Preamble, it stated that 'man is both creature 
Valemo-nos porquanto, da doutrina do Professor Celso Fiorillo, no que concerne ao princípio do desenvolvimento sustentável e sua proeminência inclusive, no tópico Direitos Humanos Ambientais: ${ }^{55}$

Constata-se que os recursos ambientais não são inesgotáveis, tornando-se inadmissível que as atividades econômicas desenvolvam-se alheias a este fato. Busca-se com isso a coexistência harmônica entre a economia e o meio ambiente. Permite-se o desenvolvimento, mas de forma sustentável, planejada, para que os recursos hoje existentes não se esgotem ou tornem-se inócuos.

Dessa forma, o princípio do desenvolvimento sustentável tem por conteúdo a manutenção das bases vitais da produção e reprodução do homem e de suas atividades, garantindo igualmente uma relação satisfatória entre homens e destes com o seu ambiente, para que futuras gerações também tenham oportunidade de desfrutar os mesmos recursos que temos hoje à nossa disposição (grifos nossos) ${ }^{56}$

Assinale-se inda que, as áreas biodiversificadas estão concentradas nas mãos das populações indígenas e não indígenas. Assim, a prática de Biopirataria atinge diretamente tais comunidades que restam lesadas em seu estilo de vida e no uso sustentável e alternativo destes recursos naturais que lhes são expropriados. ${ }^{57}$

Torna-se imperativa a adoção de medidas diligentes contra a Biopirataria, certificando assim, uma proteção ao patrimônio genético e também, ao próprio homem, em suas mais variadas relações com o meio ambiente.

Assim, delineia-se que este peculiar perigo nomeado por Biopirataria, isto é, exploração de recursos naturais, inclusive por intermédio dos conhecimentos tradicionais associados, sem respeito às condicionantes de acesso, consentimento e por fim, repartição dos lucros revertidos, atinge o Direito à Biodiversidade e o Direito à Sociodiversidade, na sua faceta seguinte, Conhecimentos Tradicionais associados.

A exploração da Biodiversidade, impulsionados pela disseminação dos Conhecimentos Tradicionais associados, vem sendo satisfeita sem respeitar os limites naturais, posto que o setor privado tende a se ocupar unicamente com a maximização de seus lucros. A árvore Taxus baccata, fonte natural do princípio ativo da droga

and moulder of his environment' and that environment protection is essential to his well-being and to the enjoyment of basic human rights; even the right to life itself'.

55 Cf. art. $5^{\circ}$., $\S 2^{\circ}$. da Constituição da República Federativa do Brasil.

56 FIORILlO, Celso Antonio Pacheco. Curso de direito ambiental brasileiro. São Paulo: Saraiva, 2011. p. 82-83.

57 WANDSCHEER, Clarissa Bueno. Socioambientalismo: uma realidade: homenagem a Carlos Frederico Marés de Souza Filho. Curitiba: Juruá, 2007. p. 63-78, p. 72-73. 
anticancerígena Taxotere da Sanofi-Aventis, quase foi suprimida na Ásia em virtude da exigência comercial pela matéria-prima. ${ }^{58}$

Destarte, preleciona o inciso II do parágrafo primeiro do art. 225 da Constituição da Republica que cabe ao Poder Público, com o fito de garantir a efetividade do direito ao meio ambiente ecologicamente equilibrado, "preservar a diversidade e a integridade do patrimônio genético do País e fiscalizar as entidades dedicadas à pesquisa e manipulação de material genético".

Além disso, o parágrafo primeiro do art. 215 da Constituição Federal doutrina que o "Estado protegerá as manifestações das culturas populares, indígenas e afro-brasileiras, e das de outros grupos participantes do processo civilizatório nacional", valorizando assim, os direitos culturais. ${ }^{59}$

Não se olvidando destes marcos constitucionais, atinentes à proteção da Biodiversidade e dos Conhecimentos Tradicionais associados, no plano infraconstitucional, pretendem conceder amparo à diversidade biológica e ao integrado conhecimento tradicional, como preponderantes, os seguintes diplomas: Convenção da Diversidade Biológica, ${ }^{60}$ e sob seu feixe, em primeiro, as Diretrizes de Bonn sobre Acesso aos Recursos Genéticos e Participação Justa e Equitativa nos Benefícios Provenientes de sua Utilização, e, em segundo, o Protocolo de Nagoya sobre Acesso aos Recursos Genéticos e Participação Justa e Equitativa nos Benefícios que se Derivem de sua Utilização ao Convênio sobre a Diversidade Biológica; Medida Provisória n. 2.186-16/2001 e respectivos decretos, n. 5.459/2005, n. 6.159/09 e n. 6.915/09 e ainda, as resoluções - atualmente no número 35 - e as seis orientações técnicas do CGEN; Lei n. 4.771/1965, Lei n. 6.938/1981, Lei n. 9.605/1998, Lei n. 9.985/2000 e Lei n. 11.284/2006, ${ }^{61}$ e finalizando, Decreto n. 4.339/02. Ademais, importa salientar que, quando se discorre sobre a repressão à Biopirataria, ${ }^{62}$ discute-se a necessidade de uma Governança Ambiental Global. Noutros

58 Como no caso do Jaborandi, em vias de extinção. Cf. RODRIGUES JÚNIOR, Edson Beas. op. cit., p. 145.

59 O patrimônio cultural brasileiro ainda é impulsionado e defendido na forma do art. 216 da Constituição do Brasil. E, notadamente, em pertinência aos direitos indígenas, o art. 231 da Constituição Federal assegura não apenas o reconhecimento às terras bem como, seus costumes e tradições.

${ }^{60}$ No art. $1^{\circ}$, fixa seus objetivos: "a conservação da diversidade biológica, a utilização sustentável de seus componentes e a repartição justa e eqüitativa dos benefícios derivados da utilização dos recursos genéticos". Tal preservação do patrimônio dar-se-á por intermédio de um acesso apropriado aos recursos genéticos e de uma transferência de tecnologia pertinente, sempre com absoluto respeito a todos os direitos sobre tais recursos e tecnologias, e, enfim, mediante um regular financiamento.

${ }_{61}$ Conferir ainda, a Lei n. 9.279/97 que trata da Propriedade Industrial.

62 Novéis ferramentas são buscadas, ad exemplum, Educação em Direitos Humanos Ambientais, como proposta trabalhada para o controle da Biopirataria. Neste sentido, a partir da consolidação do Plano Nacional de Educação em Direitos Humanos que já em seu Prólogo introduz a atenção com a natureza quando assevera que "Uma concepção contemporânea de direitos humanos incorpora os conceitos de cidadania democrática, cidadania ativa e cidadania planetária" (grifos nossos), todas elas inspiradas em valores humanistas e no princípio da diversidade, afirmando então "sua universalidade, indivisibilidade e interdependência." E ainda, 
termos, uma gestão integrada, por todos os interessados, de regras, organismos e maquinaria poderia, em muito, auxiliar nas questões ambientais por todo o mundo, não apenas, no que pertence à diminuição da biodiversidade, mas também, no que tange às mudanças climáticas, à desertificação, à crise mundial da água, ao uso indiscriminado dos recursos não renováveis, etc., como igualmente solver controvérsias conexas, de forma única com o desenvolvimento. ${ }^{63}$ De outro modo, por exemplo, apenas uma Lei Internacional sobre o Meio Ambiente já teria o condão de influenciar os ordenamentos nacionais, como aliás, um metaprincípio vinculante ao lado das correlatas normas protetivas dos direitos humanos. E, mais especialmente, poder-se-ia cogitar de estrutura institucional global para monitoramento do uso da Biosociodiversidade, com acesso até a arbitragem ${ }^{64}$ se o caso, repelindo meras regulações formais.

Independente da imprescindibilidade de uma Governança Global, não se olvidando que em termos de Direito Comparado torna-se trabalhoso trasladar perspectivas de uma realidade para outra, pode-se partir de uma análise mesmo que perfunctória de outras composições nacionais, mormente ao estudar o tema em questão - Biodiversidade - que tem inegavelmente fronteiras transnacionais. Ter-se-á o foco em alguns países megadiversos, eleitos por razões geográficas e de integração regional. ${ }^{6566}$

Assim, um país de suma importância para uma digressão é a Costa Rica.

No que tange à Biodiversidade, a norma mais relevante já publicada é a Lei de Biodiversidade n. 7.788 de 27 de maio de 1998. Em seu primeiro artigo assegura que ostenta como objetivo a conservação da Biodiversidade e a utilização dos recursos de forma sustentável e a distribuição razoável de benefícios e de custos. Nesta seara, não se afastam as patentes - que todavia, deverão atender os ditames da patenteabilidade dispostos na Lei

conferir dispositivo da CDB: “Artigo 13 - Educação e Conscientização Pública - As Partes Contratantes devem: a) Promover e estimular a compreensão da importância da conservação da diversidade biológica e das medidas necessárias a esse fim, sua divulgação pelos meios de comunicação, e a inclusão desses temas nos programas educacionais (...)". Não se esquecendo todavia, da já instrumentalizada Lei Nacional de Educação Ambiental (Lei n. 9.795/99, que dispõe sobre a educação ambiental e institui a Política Nacional de Educação Ambiental).

63 POSTIGLIONE, Amedeo. op. cit., p. 117.

${ }^{64}$ Cf. Convenção de Nova York sobre Reconhecimento e Execução de Sentenças Arbitrais Estrangeiras (1958).

65 Cf. ALFONSÍN, Marcelo López. Derecho ambiental. Buenos Aires: Ástrea, 2012.

66 Nada obstante não se tratar de país componente do rol dos megadiversos, cogente retratar a previsão seguinte sobre proteção ambiental na Constituição do Paraguai: Artículo 8 - DE LA PROTECCIÓN AMBIENTAL Las actividades susceptibles de producir alteración ambiental serán reguladas por la ley. Asimismo, ésta podrá restringir o prohibir aquellas que califique peligrosas. Se prohíbe la fabricación, el montaje, la importación, la comercialización, la posesión o el uso de armas nucleares, químicas y biológicas, así como la introducción al país de residuos tóxicos. La ley podrá extender ésta prohibición a otros elementos peligrosos; asimismo, regulará el tráfico de recursos genéticos y de su tecnología, precautelando los intereses nacionales. El delito ecológico será definido y sancionado por la ley. Todo daño al ambiente importará la obligación de recomponer e indemnizar. (g.n.) 
de Patentes de Invenção n. 6867 de 5 de abril de 1983 e suas reformas - nem quaisquer outros Direitos de Propriedade Intelectual, desde que ainda, sua exploração comercial não cause danos graves ao meio ambiente (cf. art. 78). Estabelece um título denominado "Os direitos intelectuais comunitários sui generis" no qual são reconhecidos e protegidos os conhecimentos, as práticas e inovações dos povos indígenas e das comunidades locais relacionadas com o emprego de elementos da biodiversidade e do conhecimento associado, sendo que, tais direitos de natureza coletiva dispensam prévio registro oficial e abre oportunidade de um processo participativo para as comunidades envolvidas (cf. art. 82 e ss.). Perceba que tal sistema é diferente do seguinte Patenteamento ou dos Direitos de Propriedade Intelectual outorgados sobre Conhecimentos Tradicionais associados, sendo que a Lei de Biodiversidade contudo, é omissa em dois importantes aspectos: quanto às consequências para o caso de infração a estes direitos comunitários e, em verdade, quanto ao término de proteção deste direitos ou ao seu caráter indefinido. Especificamente quanto ao acesso irregular ao Patrimônio Genético, tem-se relevante disposição consubstanciada no art. 112:

Acceso no autorizado a los elementos de la biodiversidad a quien realice exploración, bioprospección o tenga acceso a la biodiversidad, sin estar autorizado por la Oficina Técnica de la Comisión, cuando sea necesario en los términos de esta ley o se aparte de los términos en los cuales le fue otorgado el permiso, se le impondrá una multa que oscilará desde el equivalente a un salario establecido en el artículo 2 de la Ley No. 7337, hasta el equivalente a doce de estos salarios.

Importa anotar todavia que, de fato, falta a antevisão de um procedimento para a imposição da penalidade prescrita, quando do acesso não autorizado pela Comissão Nacional de Gestão da Biodiversidade (CONAGEBIO), que además, mesmo que se possível sua imposição, teria valor diminuto para justificar uma demanda de cobrança, por exemplo, em termos internacionais.

E, por fim, nada obstante a citada Lei de Biodiversidade n. 7.788 de 27 de maio de 1998 aponte o sancionamento criminal, a previsão de um tipo penal de combate à Biopirataria inexiste no ordenamento Costarriquenho, podendo apenas a conduta ser enquadrada em outros tipos penais com bens jurídicos absolutamente distintos. Veja o que diz a mencionada legislação:

\section{ARTÍCULO 111.-}

Responsabilidad penal general Salvo las situaciones ilicitas tipificadas en esta ley, la responsabilidad penal será la prescrita en el Código Penal y leyes especiales. Tratándose de delitos cometidos por funcionarios públicos o profesionales en el ejercicio de sus cargos o profesiones, la autoridad judicial podrá imponer la pena de inhabilitación 
especial por un máximo hasta de cinco años, de acuerdo con los criterios generales de imposición de las penas.

E, segundo consulta junto ao Sistema de Consulta Costarriquense de Informação Jurídica não há qualquer sentença associada a norma indicada. ${ }^{67}$ Prosseguindo, no que concerne ao Equador, outras lições podem ser de valia.

Ao vislumbrar-se entretanto, a Constituição da República do Ecuador, mormente no que nos importa, admirável é seu enfoque do Meio Ambiente.

$\mathrm{O}$ art. 71 do referido documento, ad exemplum, consagra o direito da Natureza ou Pachamama ao respeito integral à sua existência, em liberal visão. ${ }^{68}$

${ }_{67}$ Disponível em: < http://www.pgr.go.cr/scij/Busqueda/Normativa/Normas/nrm_repartidor.asp?param1=JUR \&nValor2=39796\&nValor1=1\&nValor3=74714\&nValor5=175269\&strTipM=J $>$. Acesso em: 27 nov. 2012.

68 Derechos de la naturaleza

Art. 71.- La naturaleza o Pacha Mama, donde se reproduce y realiza la vida, tiene derecho a que se respete integralmente su existencia y el mantenimiento y regeneración de sus ciclos vitales, estructura, funciones y procesos evolutivos. Toda persona, comunidad, pueblo o nacionalidad podrá exigir a la autoridad pública el cumplimiento de los derechos de la naturaleza. Para aplicar e interpretar estos derechos se observaran los principios establecidos en la Constitución, en lo que proceda. El Estado incentivará a las personas naturales y jurídicas, y a los colectivos, para que protejan la naturaleza, y promoverá el respeto a todos los elementos que forman un ecosistema.

Art. 72.- La naturaleza tiene derecho a la restauración. Esta restauración será independiente de la obligación que tienen el Estado y las personas naturales o jurídicas de Indemnizar a los individuos y colectivos que dependan de los sistemas naturales afectados. En los casos de impacto ambiental grave o permanente, incluidos los ocasionados por la explotación de los recursos naturales no renovables, el Estado establecerá los mecanismos más eficaces para alcanzar la restauración, y adoptará las medidas adecuadas para eliminar o mitigar las consecuencias ambientales nocivas.

Art. 73.- EI Estado aplicará medidas de precaución y restricción para las actividades que puedan conducir a la extinción de especies, la destrucción de ecosistemas o la alteración permanente de los ciclos naturales. Se prohíbe la introducción de organismos y material orgánico e inorgánico que puedan alterar de manera definitiva el patrimonio genético nacional.

Art. 74.- Las personas, comunidades, pueblos y nacionalidades tendrán derecho a beneficiarse del ambiente y de las riquezas naturales que les permitan el buen vivir. Los servicios ambientales no serán susceptibles de apropiación; su producción, prestación, uso y aprovechamiento serán regulados por el Estado. 
Depois, quanto à Biodiversidade ${ }^{69}$ e a Biopirataria, há previsões expressas na mesma Carta Constitucional, maiormente no art. $322,{ }^{70}$ que proíbe a apropriação de Conhecimentos Coletivos e Recursos Genéticos.

Ainda, em atendimento ao Regime Comum sobre o Acesso aos Recursos Genéticos na aplicação da Decisão n. 391 da Comunidade Andina, editou o pertinente Regulamento Nacional n. 905.

Este, dentre outras providências, demarca o Princípio do Consentimento Fundamentado Prévio, tanto do Estado quanto da Comunidade envolvida e, nesta última hipótese, com previsão de interrupção dos prazos de obtenção e tramitação da solicitação enquanto não houver a resposta; o posicionamento que exclui do âmbito de incidência desta normativa, o uso de material genético e biológico para alguns fins científicos, como taxonomia, biogeografia e filogeografia; estabelece a figura do Contrato Marco conceituado como aquele que se subscreve com fins de investigação de acesso a recursos genéticos cujos resultados não poderão ser utilizados para fins comerciais; cria ainda outra entidade, qual seja, a Instituição Nacional de Apoio, pessoa jurídica nacional, dedicada a investigação biológica de índole científica ou técnica, que acompanha o solicitante e participa junto com ele nas atividades de acesso; traz ao Instituto Ecuatoriano da Propriedade Intelectual a competência da coordenação das ações encaminhadas a determinar a existência de componente intangível associado aos recursos genéticos; apõe previsão expressa de aumento do valor dos benefícios quando o recurso genético for compartilhado com outros países; dá a resolução do Contrato de Acesso no caso de adulteração de informes e, por fim, abre a viabilidade de medidas de natureza administrativa, civil e penal para o incumprimento dos requistos de empréstimo nos Contratos Marco.

69 Biodiversidad

Art. 400.- El Estado ejercerá la soberanía sobre la biodiversidad, cuya administración y gestión se realizará con responsabilidad intergeneracional. Se declara de interés público la conservación de la biodiversidad y todos sus componentes, en particular la biodiversidad agrícola y silvestre y el patrimonio genético del país. Art. 401.- Se declara al Ecuador libre de cultivos y semillas transgénicas. Excepcionalmente, y sólo en caso de interés nacional debidamente fundamentado por la Presidencia de la República y aprobado por la Asamblea Nacional, se podrán introducir semillas y cultivos genéticamente modificados. El Estado regulará bajo estrictas normas de bioseguridad, el uso y el desarrollo de la biotecnología moderna y sus productos, así como su experimentación, uso y comercialización. Se prohíbe la aplicación de biotecnologías riesgosas o experimentales.

Art. 402.- Se prohíbe el otorgamiento de derechos, incluidos los de propiedad intelectual, sobre productos derivados o sintetizados, obtenidos a partir del conocimiento colectivo asociado a la biodiversidad nacional. Art. 403.- El Estado no se comprometerá en convenios o acuerdos de cooperación que incluyan cláusulas que menoscaben la conservación y el manejo sustentable de la biodiversidad, la salud humana y los derechos colectivos y de la naturaleza.

70 Art. 322.- Se reconoce la propiedad intelectual de acuerdo con las condiciones que señale la ley. Se prohíbe toda forma de apropiación de conocimientos colectivos, en el ámbito de las ciencias, tecnologías y saberes ancestrales. Se prohíbe también la apropiación sobre los recursos genéticos que contienen la diversidad biológica y la agro-biodiversidad. 
Especialmente no tema em testilha, ${ }^{71}$ vale sublinhar a recente reforma penal ocorrida com a Lei n. 99-49 de 25 de janeiro de 2000, que cuida dos Delitos contra o Patrimônio Cultural assim como, dos Delitos contra o Meio Ambiente que incluem os ecológicos. Veja então, no Código Penal Ecuatoriano, no Capítulo X-A: Dos Delitos contra o Meio Ambiente, as ímpares prescrições acrescentadas, mormente os crimes funcionais postos nos versículos 437-E e 437-J, as medidas cautelares do ditame 437-K e, para finalizar:

Art. 437-F. - El que cace, capture, recolecte, extraiga o comercialice, especies de flora o fauna que estén legalmente protegidas, contraviniendo las disposiciones legales y reglamentarias sobre la materia, será reprimido con prisión de uno a tres años.

La pena será de prisión de dos a cuatro años cuando:

a) El hecho se cometa en período de producción de semilla o de reproducción o crecimiento de las especies;

b) El hecho se cometa contra especies en peligro de extinción; $\mathrm{o}$,

c) El hecho se cometa mediante el uso de explosivos, sustancias tóxicas, inflamables o radiactivas.

Um país que serve de modelo na temática é o Peru.

E se não é tido como o país mais ambientalista da América, como o Chile, o Peru dá mostras de evolução e exemplos no combate à Biopirataria.

Em primeiro, vale salientar que, existe a Lei de Proteção ao Acesso a Diversidade Biológica Peruana e aos Conhecimentos Coletivos dos Povos Indígenas, isto é, Lei n. 28.216. Como sua ementa indica pretende assegurar a defesa da Biosociodiversidade Peruana (cf. ainda, art. $1^{\circ}$ ) contra atos de Biopirataria (art. 4", alínea "b"). Para tanto, cria uma Comissão Nacional de Coordenação e Ação (cf. art. $2^{\circ}$ ) que ostenta as seguintes funções (art. $\left.4^{\circ}\right)$ :

a) Crear y mantener un Registro de los Recursos Biológicos y Conocimientos Colectivos de los Pueblos Indígenas del Perú.

b) Proteger de actos de biopiratería.

71 Perceba, nada obstante, noutros termos, a preocupação com o patrimônio genético e com a Biodiversidade: Art. 437-B.- El que infringiere las normas sobre protección del ambiente, vertiendo residuos de cualquier naturaleza, por encima de los límites fijados de conformidad con la ley, si tal acción causare o pudiere causar perjuicio o alteraciones a la flora, la fauna, el potencial genético, los recursos hidrobiológicos o la biodiversidad, será reprimido con prisión de uno a tres años, si el hecho no constituyere un delito más severamente reprimido. (g.n.). 
c) Identificar y efectuar el seguimiento de las solicitudes de patentes de invención presentadas o patentes de invención concedidas en el extranjero, relacionadas con recursos biológicos o con conocimientos colectivos de los pueblos indígenas del Perú.

d) Evaluar técnicamente las solicitudes presentadas y las patentes concedidas, precisadas en el literal anterior.

e) Emitir informes acerca de los casos estudiados, realizando recomendaciones a seguir en las instancias del Estado competentes.

f) Interponer acciones de oposición o acciones de nulidad contra las solicitudes de patentes de invención o contrapatentes concedidas en el extranjero, que se relacionen con material biológico o genético del Perú o los conocimientos colectivos de sus pueblos indígenas y nativos.

g) Establecer canales permanentes de información y diálogo con las oficinas de propiedad industrial de otros países.

h) Promover vínculos con los organismos de participación regional del Estado y de la Sociedad Civil.

i) Elaborar propuestas con la finalidad de proteger en los diversos foros internacionales la posición del Estado y de los pueblos indígenas y nativos del Perú, con la finalidad de prevenir y evitar los actos de biopiratería.

E, com fulcro nesta regulamentação ambiental, faz-se possível a interessante tipificação penal a seguir que abarca as duas frentes de ataque da Biopirataria, ou seja, tanto o Patrimônio Genético, quanto os Conhecimentos Tradicionais Associados. Algumas prévias observações. Em primeiro que, o Código Penal Peruano, na Exposição de Motivos, classifica o meio ambiente como bem jurídico de caráter socioeconômico. Depois, há previsões de crimes funcionais, responsabilidade penal dos representantes legais da pessoa jurídica em que se deu algum delito ecológico e medidas cautelares determinadas pelo julgador penal.

Todavia, o mais relevante é a prescrição do crime do Tráfico Ilegal de Recursos Genéticos que parece afinal, deter em absoluto a previsão de um tipo penal para a Biopirataria do Patrimônio Genético.

Artículo 308-D.- Tráfico ilegal de recursos genéticos

El que adquiere, vende, transporta, almacena, importa, exporta o reexporta, de forma no autorizada, recursos genéticos de especies de flora y/o fauna silvestre protegidas por la legislación nacional, será reprimido con pena privativa 
de libertad no menor de tres años ni mayor de cinco años y con ciento ochenta a cuatrocientos días-multa.

La misma pena será aplicable para el que a sabiendas financia, de modo que sin su cooperación no se hubiera podido cometer las actividades señaladas en el primer párrafo, y asimismo al que las dirige u organiza.

Outro país megadiverso é a África do Sul.

Também ela possui um Plano Estratégico para Assuntos Ambientais (01 de Abril de 2012 a 31 de Março de 2017), notadamente para a Biodiversidade e Conservação. Nele, define-se um projeto para um desenvolvimento justo, ambicioso e juridicamente vinculativo em futuro multilateral e baseado em regras globais. E a Biopirataria surge como prioridade do Governo ao combater a criminalidade e a corrupção.

Há ênfase nos pretendidos benefícios econômicos daquela rica Biosfera, buscando-se garantir um desenvolvimento econômico que seja sustentável sem ofensa ao Meio Ambiente, numa abordagem preservacionista e desenvolvimentista. A proteção da Biodiversidade aflora então como, um instrumento inclusive para geração de empregos e rendas para aqueles indivíduos não qualificados no mercado formal. A abordagem segue níveis de atuação global, nacional e regional. E, a imprescindibilidade de uma legislação ambiental adequada surge como meta para redução do déficit entre a normativa e o cumprimento desta.

De mais interessante no Plano de Ação que se segue é a consideração de que a Biodiversidade deve integrar todos os demais planos governamentais, numa visão abrangente da Biodiversidade. A Biodiversidade que, de fato, ostenta um papel relevantíssimo nas planificações de subsistência, não tem seu valor associado em diversificados cálculos para tomada de decisões. Noutras palavras, a Biodiversidade não compõe o Produto Interno Bruto (PIB). A isto, agregue-se a urbanização e o Apartheid que restam por alienar todas as pessoas da Natureza. E o caminho para a desconsideração da Biodiversidade está aberto.

Não se olvida nesta seara, a área de Bioprospecção e "privatização" dos recursos biológicos como espaços que demandam cuidados, dentre eles, um acelerado incremento de uma legislação protetiva, inclusive dos indivíduos nos Conhecimentos Tradicionais associados. Destarte, uma ampla revisão das leis intelectuais da África do Sul de propriedade é recomendada, combinada com um processo de política pública para explorar a interface entre aqueles relacionados ao Comércio dos Direitos de Propriedade (TRIPS) e da Convenção sobre Diversidade Biológica (CDB), tudo com o fito de garantir o exame da ABS (Acordo de Acesso e Compartilhamento de Lucros - ABS em inglês) e questões de conhecimentos tradicionais e, rever a abordagem da África do Sul sobre política ao patenteamento da vida. 
Enfim, sobre Biodiversidade tem-se como principal documento "National Environmental Management: Biodiversity Act, 2004". Nele há, além das óbvias diretrizes sobre Biodiversidade, um Capítulo Nove sobre Infrações e Penalidades, inclusive de cunho penal. ${ }^{72}$

\section{ANTEPROJETO DE LEI DO CRIME DE BIOPIRATARIA}

\subsection{Anteprojeto de Lei}

\subsubsection{Artigos de Lei}

\section{Anteprojeto de Lei do Crime de Biopirataria}

Disciplina as sanções aplicáveis às condutas lesivas ao patrimônio genético ou ao conhecimento tradicional associado e dá outras providências.

\section{Capítulo I - Das Disposições Preliminares}

Art. $1^{\circ}$. Este Anteprojeto de lei disciplina as sanções aplicáveis às condutas lesivas

\section{Offences}

101. (1) A person is guilty of an offence if that person contravenes or fails to comply with a provision of-

(a) section 57(1), 65(1), 67(2), 71(1) or 81(1);

(b) a notice published in terms of section 57(2); or

(c) a directive issued in terms of section 69(2) or 73(3).

(2) A person who is the holder of a permit is guilty of an offence if that person-

(a) contravenes or fails to comply with a provision of section 69(1) or 73(1);

(b) performs the activity for which the permit was issued otherwise that in accordance with any conditions subject to which the permit was issued; or

(c) permits or allows any other person to do, or to omit to do, anything which is an offence in terms of paragraph (a) or (b).

(3) A person is guilty of an offence if that person-

(a) fraudulently alters any permit;

(b) fabricates or forges any document for the purpose of passing it as a permit;

(c) passes, uses, alters or has in his or her possession any altered or false document purporting to be a permit; or

(d) knowingly makes any false statement or report for the purpose of obtaining a permit.

Penalties

102. (1) A person convicted of an offence in terms of section 101 is liable to a fine, or to imprisonment for a period not exceeding five years, or to both fine and such imprisonment.

(2) A fine in terms of subsection (1) may not exceed-

(a) an amount prescabed in terms of the Adjustment of Fines Act, 1991 (Act No. 101 of 1991); or

(b) if a person is convicted of an offence involving a specimen of a listed threatened or protected species, an amount determined in terms of paragraph (a) or which is equal to three times the commercial value of the specimen in respect of which the offence was committed, whichever is the greater. 
ao patrimônio genético, ao conhecimento tradicional associado, à repartição dos benefícios e à concessão de direito de propriedade industrial.

\section{Capítulo II - Dos Crimes contra o Patrimônio Genético}

Art. $2^{\circ}$. Acessar ou por qualquer outro meio identificar componente do patrimônio genético, para fins de pesquisa científica, em desacordo com a legislação vigente e com a autorização obtida.

Pena - prisão, de 2 (dois) a 6 (seis) anos, e multa.

$\S \quad 1^{\circ}$. Nas mesmas penas incorre quem coletar, ou por qualquer outro meio remover ou ainda, armazenar espécime vegetal, animal ou microbiana, para fins de pesquisa científica, em desacordo com a legislação vigente e com a autorização obtida.

$\S \quad 2^{\circ}$. Acessar ou por qualquer outro meio identificar componente do patrimônio genético, para fins de bioprospecção ou biotecnologia, em desacordo com a legislação vigente e com a autorização obtida.

Pena - prisão, de 3 (três) a 8 (oito) anos, e multa.

$\S 3^{\circ}$. Nas mesmas penas incorre quem coletar, ou por qualquer outro meio remover ou ainda, armazenar espécime vegetal, animal ou microbiana, para fins de bioprospecção ou biotecnologia, em desacordo com a legislação vigente e com a autorização obtida.

$\S \quad 4^{\circ}$. Se o crime é culposo, a pena será reduzida à metade.

Art. $3^{\circ}$. Usar componente do patrimônio genético em desacordo com a legislação vigente e com a autorização obtida.

Pena: prisão, de 2 (dois) a 6 (seis) anos, e multa.

$\S 1^{\text {o }}$. Usar componente do patrimônio genético, para fins econômicos, em desacordo com a legislação vigente e com a autorização obtida.

Pena: prisão, de 3 (três) a 8 (oito) anos, e multa.

$\S \quad 2^{\circ}$. Usar componente do patrimônio genético, para fins de obtenção de direito de propriedade industrial, em desacordo com a legislação vigente e com a autorização obtida.

Pena: prisão, de 4 (quatro) a 12 (doze) anos, e multa.

$\S \quad 3^{\circ}$. Se o crime é culposo, a pena será reduzida à metade. 
Art. $4^{\circ}$. Remeter ou por qualquer outro meio transportar para o exterior componente do patrimônio genético em desacordo com a legislação vigente e com a autorização obtida.

Pena: prisão, de 3 (três) a 8 (oito) anos, e multa.

Parágrafo único. Se o crime é culposo, a pena será reduzida à metade.

Art. $5^{\circ}$. Deixar de repartir justa e equitativamente os benefícios monetários ou não resultantes do uso de componente do patrimônio genético em desacordo com a legislação vigente e com a autorização obtida.

Pena: prisão, de 2 (dois) a 6 (seis) anos, e multa.

Parágrafo único. Se o crime é culposo, a pena será reduzida à metade.

\section{Capítulo III - Dos Crimes contra o Conhecimento Tradicional Associado}

Art. $6^{\circ}$. Acessar ou por qualquer outro meio obter conhecimento tradicional associado ao patrimônio genético, para fins de pesquisa científica, em desacordo com a legislação vigente e com a autorização obtida.

Pena: prisão, de 2 (dois) a 6 (seis) anos, e multa.

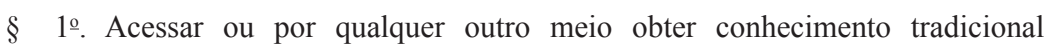
associado ao patrimônio genético, para fins de bioprospecção ou biotecnologia, em desacordo com a legislação vigente e com a autorização obtida.

Pena: prisão, de 3 (três) a 8 (oito) anos, e multa.

$\S 2$ o. Se o crime é culposo, a pena será reduzida à metade.

Art. $7^{\circ}$. Divulgar ou transmitir conhecimento tradicional associado ao patrimônio genético em desacordo com a legislação vigente e com a autorização obtida.

Pena: prisão, de 3 (três) a 8 (oito) anos, e multa.

Parágrafo único. Se o crime é culposo, a pena será reduzida à metade.

\section{Capítulo IV - Dos Crimes contra a Administração da Biodiversidade}

Art. 8. Falsificar ou alterar, por qualquer meio, documento utilizado para prova de fato que permita o acesso a componente do patrimônio genético, ao conhecimento tradicional associado ao patrimônio genético ou à repartição de benefícios.

Pena: prisão, de 2 (dois) a 6 (seis) anos, e multa.

$\S 1^{\circ}$. Nas mesmas penas incorre quem falsificar ou alterar, por qualquer meio, 
documento utilizado com o propósito de simular o cumprimento de obrigações derivadas do acesso a componente do patrimônio genético, ao conhecimento tradicional associado ao patrimônio genético ou à repartição de benefícios.

$\S \quad 2^{\circ}$. Se o crime é culposo, a pena será reduzida à metade.

Art. 9. Omitir declaração que deveria constar, inserir ou fazer inserir, por qualquer meio, declaração falsa em documento utilizado para prova de fato que permita o acesso a componente do patrimônio genético, ao conhecimento tradicional associado ao patrimônio genético ou à repartição de benefícios.

Pena: prisão, de 2 (dois) a 6 (seis) anos, e multa.

$\S \quad 1^{\circ}$. Nas mesmas penas incide quem omitir declaração que deveria constar, inserir ou fazer inserir, por qualquer meio, declaração falsa em documento utilizado com o propósito de simular o cumprimento de obrigações derivadas do acesso a componente do patrimônio genético, ao conhecimento tradicional associado ao patrimônio genético ou à repartição de benefícios.

$\S 2^{\circ}$. Omitir a origem de componente do patrimônio genético ou de conhecimento tradicional associado ao patrimônio genético, inserir ou fazer inserir, por qualquer meio, origem falsa em publicação ou transmissão ou qualquer forma de divulgação.

Pena: prisão, de 3 (três) a 8 (oito) anos, e multa.

$\S 3^{\circ}$. Se o crime é culposo, a pena será reduzida à metade.

Art. 10. Destruir ou ocultar, por qualquer meio, documento de que não se podia dispor em conformidade com a legislação vigente e com a autorização obtida de acesso a componente do patrimônio genético, ao conhecimento tradicional associado ao patrimônio genético ou à repartição de benefícios.

Pena: prisão, de 2 (dois) a 6 (seis) anos, e multa.

Parágrafo único. Se o crime é culposo, a pena será reduzida à metade.

Art. 11. As penas cominadas nos artigos 8, 9 e 10 aumentam-se em até a metade, se o agente é funcionário público e comete o crime prevalecendo-se do cargo.

Art. 12. Obstar ou dificultar a ação fiscalizadora do Poder Público no trato de questões de acesso a componente do patrimônio genético, ao conhecimento tradicional associado ao patrimônio genético ou à repartição de benefícios.

Pena: prisão, de 2 (dois) a 4 (quatro) anos, e multa. 
Parágrafo único. Se o crime é culposo, a pena será reduzida à metade.

Art. 13. Deixar de cumprir as medidas determinadas pelo Poder Público destinadas a impedir ou minimizar o dano à diversidade biológica decorrente do acesso a componente do patrimônio genético.

Pena: prisão, de 3 (três) a 8 (oito) anos, e multa.

Parágrafo único. Se o crime é culposo, a pena será reduzida à metade.

\section{Capítulo V - Das Disposições Gerais}

Art. 14. As penas cominadas nos Capítulos II, III e IV aumentam-se em até a metade, se qualquer dos crimes é cometido:

I - contra espécies de endemismo estrito;

II - contra espécies constantes da lista oficial da fauna e da flora brasileiras ameaçadas de extinção e dos Anexos I e II da Convenção sobre o Comércio Internacional das Espécies da Flora e Fauna Selvagens em Perigo de Extinção - CITES;

III - em áreas protegidas ou

IV - em qualquer outra situação que cause perigo de dano grave à diversidade biológica.

\section{Capítulo VI - Das Disposições Finais}

Art. 15. Esta lei entra em vigor após decorridos noventa dias de sua publicação

oficial.

Art. 16. Aplicam-se subsidiariamente a esta Lei as disposições da Lei dos Crimes Ambientais, do Código Penal e do Código de Processo Penal.

\subsubsection{Justificativa}

Este Anteprojeto propende, sob o prisma do Direito Penal, a coibir a Biopirataria percebida prioritariamente como o acesso irregular ao Patrimônio Genético. Noutros termos, Biopirataria consiste no ato de aceder ao Patrimônio Genético em desrespeito às diversificadas normativas ambientais, atingindo pois, o Direito à Biodiversidade.

Versa então, sobre mote de elevada acuidade, qual seja, a proteção do Patrimônio Genético cuja assolação estará a tocar a vida de todas as espécies na Terra; 
afinal, a diversidade biológica constitui fundamental suporte tangível para os seres vivos e fonte intangível de soluções técnicas.

Ostenta como pressupostos basilares a Convenção das Nações Unidas sobre Diversidade Biológica, da qual o Brasil é signatário, tendo-a ratificado (Decreto Legislativo n. 02/1994) e promulgado (Decreto n. 2.519/98) e ainda, a Constituição Federal do Brasil de 1988 que prenotou capítulo próprio ao meio ambiente - Capítulo VI, Título VIII (“Da Ordem Social”) - estabelecendo em seu art. 225, caput, que: “Todos têm direito ao meio ambiente ecologicamente equilibrado, bem de uso comum do povo essencial à sadia qualidade de vida, impondo-se ao Poder Público e à coletividade o dever de defendê-lo e preservá-lo para as presentes e futuras gerações" e, mormente no que concerne ao fulcro do Anteprojeto, o inciso II do parágrafo $1^{\circ}$ do mesmo dispositivo que assim prediz: "Para assegurar a efetividade desse direito, incumbe ao Poder Público: (...) II - preservar a diversidade e a integridade do patrimônio genético do País e fiscalizar as entidades dedicadas à pesquisa e manipulação de material genético".

Há ainda, todo um arcabouço jurídico que disciplina o tema composto sobretudo pela Medida Provisória n. 2.186-16, de 23 de Agosto de 2001, implementada por meio dos Decretos n. 4.946/03 - que altera o Decreto n. 3.945/01 - e ns. 5.459/05, 6.159/09 e 6.915/09 e das resoluções - atualmente no número 35 - e das seis orientações técnicas do CGEN.

Entretanto se observa, em termos pragmáticos, insuficiência dos recursos acionados. De verdade, é inexecutável a estimativa do quantum o Brasil é despojado com a Biopirataria, maiormente com a prática do patenteamento em âmbito internacional.

E assim, visando suprir esta lacuna, oferta-se o presente Anteprojeto.

Cuida-se de reconhecer a imprescindibilidade da proteção de um novel bem jurídico, qual seja, a Biodiversidade, em seara penal.

Por isto mesmo, este Anteprojeto não se cinge a elementares ajustes de outras leis penais que precariamente são empregadas, mas sim, de um original sistema cujo tópico é a tutela da Biodiversidade.

De sabença, pugnar por uma proposta de edificação de uma nova figura penal ambiental pode redundar em acerbas críticas quanto ao simbolismo do Direito Criminal e quanto à existência de bens jurídicos supraindividuais, contudo, a obediência a rígidos critérios de técnica redacional, com composição de estilo claro a obstar ambiguidades, e ainda, com emprego de todo o instrumental normativo em absoluta harmonia com o Princípio da Legalidade, dá supedâneo ao Anteprojeto.

Não se olvida entretanto, que há concomitante urgência de uma poderosa materialização da Política Nacional do Meio Ambiente, de uma vigorosa atuação da Polícia Judiciária, de uma cônscia cátedra Julgadora e de uma Governança Ambiental global. 
Destarte, o Anteprojeto pretende abolir, com o manejo do Direito Penal Ambiental, o Acesso Irregular ao Patrimônio Genético.

Recorda-se contudo que existe um perigoso entorno que bem assim deve ser obstaculizado, consistente no Acesso Irregular ao Conhecimento Tradicional Associado e em outros comportamentos também prejudiciais ao Patrimônio Genético, ad exemplum, uso, remessa para o exterior, transporte e armazenamento, não repartição dos benefícios, divulgação do Conhecimento Tradicional associado e, enfim, condutas contra a Administração da Biodiversidade.

O Anteprojeto veicula Infrações contra o Patrimônio Genético, contra os Conhecimentos Tradicionais Associados e contra a Administração da Biodiversidade.

Convém realçar por derradeiro que, esta propositura traz singela pretensão de inaugurar os debates sobre um tipo penal principal de Biopirataria e, por deslinde, sobre a reestruturação de todo o aparelho vigente.

\section{Conclusão}

Enfocou-se o tema Biopirataria sob a perspectiva da imprescindibilidade ou não de um tipo penal.

E assim o fez porque ao definir-se Biopirataria, depreendeu-se que inexiste tipificação do crime de Biopirataria, o que moveria à aplicação, tão somente de maneira incipiente, da Lei de Crimes Ambientais (Lei n. 9.605/98).

Independente de lacuna jurídica acerca da concepção de Biopirataria valeuse de seu costumeiro emprego como acesso irregular ao Patrimônio Genético e ainda, aos Conhecimentos Tradicionais associados.

Não se pode olvidar, contudo que, além destas duas grandes facetas, outras ações do mesmo modo conformam a questão, reclamando resposta proibitiva, ad exemplum, o não compartilhamento dos benefícios, ou ainda, o desvio na utilização do Patrimônio Genético ou dos Conhecimentos Tradicionais associados, no envio para o exterior, no transporte e armazenamento do Patrimônio Genético, na propalação dos Conhecimentos Tradicionais associados e, enfim, variadas condutas contra a Administração da Biodiversidade.

Há ainda quem entenda que Biopirataria também alcança a proteção pelos Direitos de Propriedade Intelectual de inovações que em verdade são cópias ou simplórias modificações dos primeiros direitos.

Partiu-se de proposições descobertas ao longo da investigação, quais sejam, o princípio do menor custo moral que abalizando eticamente toda a controvérsia sobre a interação homem e natureza prega que se deve sempre sopesar o custo ético de todos os procedimentos e assim, a presença de alternativas com menor custo moral para atingir os 
mesmos objetivos; e ainda, o magnífico valor do fato estudado que fundando a incidência do Direito Penal, recrudesce a constância de um prévio direito natural, de uma exigência superior de justiça que afiança tal tutela e pois assim, aflorou a ilação sobre a cogência de um tipo penal.

Assim, apurou-se a incriminação como resposta à Biopirataria e daí, a edificação de um tipo penal cujo Bem Jurídico basilar elege-se como algo novedoso, isto é, a Biodiversidade, originada do grego bios, perfilhada esta como a diversidade biológica ou variedade da natureza viva, de organismos vivos de todas as origens e os complexos ecológicos de que fazem parte, tudo sem repelir, todavia, um imperioso e multifacetário arcabouço de ações para, de verdade, oferecer proteção à solvência desta altercação, ad exemplum, uma forte concretização da Política Nacional do Meio Ambiente, inclusive no que concerne à Educação em Direitos Humanos Ambientais, uma poderosa atuação da Polícia Judiciária e uma consciencioso cátedra Julgadora.

Destarte, a solução para a problemática explorada - Biopirataria: reflexões sobre um tipo penal - redundou na ilação da indispensabilidade não somente num único versículo criminal, mas de toda uma propositura contra a Biopirataria a encerrar desde o Acesso Irregular ao Patrimônio Genético e aos Conhecimentos Tradicionais Associados, caminhando por condutas tangenciais ruinosas, ad exemplum, a não repartição justa e equitativa dos benefícios, ou ainda, a anormalidade no uso do Patrimônio Genético ou dos Conhecimentos Tradicionais associados, na remessa para o exterior, no transporte e armazenamento do Patrimônio Genético, na divulgação dos Conhecimentos Tradicionais associados e, afinal, em variadas condutas contra uma Administração Pública da Biodiversidade.

E, dentre todas estas sugestões, tem-se o $\S 2^{\circ}$ do art. $2^{\circ}$ do Capítulo II como o capital para a inteligência no combate à Biopirataria. Veja: "Acessar ou por qualquer outro meio identificar componente do patrimônio genético, para fins de bioprospecção ou biotecnologia, em desacordo com a legislação vigente e com a autorização obtida. Pena prisão, de 3 (três) a 8 (oito) anos, e multa".

Versa sobre passo essencial para a perpetração da Biopirataria que suprime, por fim, a Biodiversidade. Pretende-se pois, com a conduta supra, identificar uma informação genética e traçar investigações para fins de exploração econômica, realce-se, tudo em contrariedade às normas ambientais protetivas. No mais, ostentou-se resposta penal de difícil temática com a seguinte equação: valor do bem jurídico e intensidade criminal.

Sustenta-se porquanto, um Anteprojeto de Lei contra a Biopirataria cuja justificativa além das já aludidas premissas do menor custo moral e da pertinência de um Direito Penal Ambiental, ancorou-se em constatada insuficiência dos demais instrumentos para cuidar do mote. Noutras palavras, medidas nacionais de cunho administrativo, 
inclusive políticas públicas, ou de natureza civil, bem como, providências internacionais, primordialmente a Convenção da Diversidade Biológica apresentaram-se débeis em face da Biopirataria. Esta última notadamente porque alijada de instrumentos sancionatórios para o descumprimento de suas diretrizes.

A Biodiversidade, portanto, prestou-se como inarredável interesse cardeal de relevância o bastante para quando da sujeição a severos ataques, como na hipótese em testilha, demandar sua tutela em sede de Bem Jurídico Penal.

De fato, em respeito a "Direitos próprios da Natureza" ou diante do desassossego da sociedade com a perda ambiental, está a se incriminar lesão ou perigo de lesão ao ecossistema, fundamentando a seara dos delitos ambientais, dentre os quais, se pugna, pela edificação de um tipo objetivo de Biopirataria.

De novo, a diversidade biológica ou reservatório genético é sabidamente exauriente. As técnicas bioprospectoras podem destruir irremediavelmente o ecossistema. E, recorde-se que, a Biodiversidade responde afinal, pela adaptação das espécies à mudanças ambientais, acontecimento basilar na Biotecnologia que pode selecionar ou mesclar material genético já existente na natureza mas não, criá-los, sendo por conseguinte, de inegável relevância sua tutela.

Depreendeu-se contudo que o capítulo Biopirataria sob o prisma penal é pouco esquadrinhado, mesmo nos países megadiversos, exemplifica-se com a Costa Rica, cuja ausência de uma lei penal especial faz-se perceber, nada obstante sua avançada legislação acerca de Biodiversidade aponte o sancionamento criminal, a previsão de um tipo penal de combate à Biopirataria inexiste no ordenamento Costariquenho, podendo apenas a conduta ser inserida em outros tipos penais com bens jurídicos absolutamente distintos.

Enfim, cuida-se de novel matéria, haja vista a originalidade da Convenção da Diversidade Biológica e de seus protocolos - de Bonn sobre Acesso aos Recursos Genéticos e Participação Justa e Equitativa nos Benefícios Provenientes de sua Utilização, e de Nagoya sobre Acesso aos Recursos Genéticos e Participação Justa e Equitativa nos Benefícios que se Derivem de sua Utilização ao Convênio sobre a Diversidade Biológica, este último sequer em vigência - e trata-se de assunto com tipificação extremamente complexa que reclama detalhamento desde a identificação do Bem Jurídico Penal, percorrendo os diferençados núcleos verbais e encerrando com o patamar sancionatório.

Aliás, tal enredamento principia pela novidade do Bem Jurídico Penal de natureza difusa com seus defensores e detratores, isto é, a Biodiversidade e a Diversidade Biológica e o Patrimônio Genético e/ou Conhecimentos Tradicionais associados no ônus de conceituação por caráter de norma penal em branco.

A hodierna tendência expansiva do Direito Penal, em consonância ao alargamento advindo do Estado Democrático do Direito, em repúdio ao círculo clássico de 
tutela e pois, admissão de novos interesses dignos de proteção penal com feição coletiva ou supraindividual, como a Biodiversidade, põe por terra quaisquer objeções quanto à aceitabilidade deste jovem Bem Jurídico que entretanto, apresenta sim, âmbito que se imiscui com o Direito Administrativo, não se cingindo entretanto, a ser seu mero reforço.

Um parêntese merece ser aqui aposto: no que concerne aos Conhecimentos Tradicionais associados ao Patrimônio Genético, seria de inegável utilidade uma pesquisa de campo para maior aprofundamento, mesmo porque já se lançou o prestígio autônomo deste bem. Também, as informações e práticas de toda uma comunidade tradicional são de indiscutível peso, mormente pelo prisma do acesso facilitado à Biodiversidade.

Depois, advém a eleição dos verbos numa fina equação entre precisão normativa e eficácia. $\mathrm{O}$ estabelecimento da identidade dos inúmeros comportamentos aptos a prejudicar a Biodiversidade repudia o "déficit de eficiência".

Tudo agregado à técnica redacional e emprego do instrumental normativo em absoluta harmonia ao Princípio da Legalidade.

E, em derradeiro, a inóspita seara da penalização sem qualquer parâmetro, inclusive por conta de uma absoluta ausência de eco na sociedade, mas sem esquecer que a sanção deve corresponder à altura da dignidade humana tanto do Sujeito Ativo como do Sujeito Passivo mais que, mera visão impeditiva da prática de novos delitos.

Em realidade, depreendeu-se que se a resposta penal é de autoridade, mister não olvidar que se aventa como ultima ratio a nascer por causa de uma ainda inatividade conjunta dos países megadiversos destituídos de uma governança global. Contexto inadmissível diante da pujança deste grupo que possui aproximadamente $70 \%$ da Biodiversidade do planeta e cerca de $45 \%$ da população mundial num equivalente de Sociodiversidade. Um mergulho nesta questão é absolutamente mandatório e urgente.

São Paulo, janeiro de 2013.

\section{Referências}

ALENCAR, Gisela S. de. Biopolítica, biodiplomacia e a Convenção sobre Diversidade Biológica 1992: evolução e desafios para implementação. Revista de Direito Ambiental, São Paulo, v. 3, n. 1, p. 82-103, set. 1996.

AMARAL JÚNIOR, Alberto do. Comércio internacional e a proteção do meio ambiente. São Paulo: Atlas, 2011.

AMBIENTE Brasil. Biopirataria na Amazônia. Disponível em: <http://ambientes.ambientebrasil. com.br/amazonia/floresta_amazonica/biopirataria_na_am azonia.html >. Acesso em: 28 out. 2011. 
AMELUNG, Knut. Contribución a la crítica del sistema jurídico-penal de orientación políticocriminal de Roxin. In: SCHÜNEMANN, Bernd (Comp.). El sistema moderno del derecho penal: cuestiones fundamentales. Buenos Aires: B de F, 2012. p. 99-120.

BARATTA, Alessandro. Ecologia, economia, democrazia e il patto sociale della modernità. Dei Delitti e Delle Pene: Rivista de Studi Sociali, Storici e Giuridici Sulla Questione Criminale, Bologna, n. 1/2, p. 9-24, 2000.

BARRAL, Welber; PIMENTEL, Luiz Otávio. Propriedade intelectual e desenvolvimento. Florianópolis: Fundação Boiteux, 2007.

BIODIVERSIDADE - valor econômico e social. Regulamentação do acesso à biodiversidade ainda não é definitiva. ComCiência, 10 jun. 2001. Disponível em: <http://www.comciencia.br/ reportagens/biodiversidade/bio05.htm>. Acesso em: 28 jan. 2012.

BIODIVERSITY hotspots. Megadiverse countries. Disponível em: < http://www.environment.gov. $\mathrm{au} /$ biodiversity/hotspots/index.html $>$. Acesso em: 15 jul. 2012

BITTAR, Eduardo C. B. O direito na pós-modernidade e reflexões frankfurtianas. Rio de Janeiro: Forense Universitária, 2009.

CABRERA MEDAGLIA, José Alberto. Bioderecho: propiedad intelectual, comercio y ambiente. San José, C.R.: EUNED, 2011.

. Biopiratería en America Latina: desafios y respuestas legales e institucionales. Texto não publicado, cedido pelo autor.

CÂMARA DOS DEPUTADOS. Andamento da proposição junto à câmara dos deputados federais. Disponível em: <http://www.camara.gov.br/proposicoesWeb/fichadetramitacao?idProposic $\mathrm{ao}=21168>$. Acesso em: 09 jun. 2011.

. Comissão parlamentar de inquérito que investiga o tráfico de animais e plantas silvestres brasileiras, a exploração e comércio ilegal de madeira e a biopirataria no país (CPIBIOPI). Relatório final/2006. Disponível em: <http://camara.gov.br/comissoes.htm>. Acesso em: 23 out. 2007.

CPI da biopirataria: relatório final. Brasília/DF: Centro de Documentação e Informação. Coordenação de Publicações, 2007. 2a Audiência Pública da CPIBIOPI - 17/11/04. João Paulo Ribeiro Capobianco, Secretário de Biodiversidade e Florestas do MMA. Disponível em: < http:// apache.camara.gov.br/portal/arquivos/Camara/internet/publicacoes/edicoes/lancamentos/CPI_ Biopirataria.pdf>. Acesso em: 28 out. 2011.

CAMPOS, Pedro Celso. Ecologia humana: o pressuposto da ética na preservação do meio ambiente: breve história sobre origens e conceitos do movimento ambientalista. Disponível em: $<$ http://www. razonypalabra.org.mx/libros/libros/ecologiaetica.pdf>. Acesso em: 20 jul. 2010.

CANOtilho, J. J. Gomes. Proteção do ambiente e direito de propriedade. Coimbra: Coimbra, 1995. 
CARNEIRO, Ana Cláudia Mamede. Acesso a recursos genéticos, conhecimentos tradicionais associados e repartição de benefícios. Revista da ABPI - Associação Brasileira da Propriedade Intelectual, n. 88, p. 3-16, maio/jun. 2007.

CARVAlHO, Nuno Pires de. Em defesa da biodiversidade [Entrevista]. Revista Pesquisa FAPESP, ed. 84, p. 17-20, fev. 2003. Disponível em: <http://revistapesquisa.fapesp. br/?art=2061\&bd=1\&pg=2\&lg=>. Acesso em: 23 jun. 2011.

COSTA JÚNIOR, Paulo José da. Direito penal ecológico. Rio de Janeiro: Forense, 1996.

D’AVILA, Fábio Roberto. O ilícito penal nos crimes ambientais: algumas reflexões sobre a ofensa a bens jurídicos e os crimes de perigo abstrato no âmbito do direito penal ambiental. Revista Brasileira de Ciências Criminais, São Paulo, v. 67, p. 29-58, 2007.

; SOUZA, Paulo Vinicius Sporleder de (Coords.). Direito penal secundário: estudos sobre crimes econômicos, ambientais, informáticos e outras questões. São Paulo: Ed. Revista dos Tribunais; Coimbra: Coimbra Ed., 2006.

D'INCAIO, Maria Ângela. Limites culturais na responsabilidade de conservação da biodiversidade. In: D'INCAIO, Maria Ângela; SILVEIRA, Isolda Maciel da. A Amazônia e a crise de modernização. Belém, Museu Paraense Emílio Goeldi, 2009.

DEL NERO, Patrícia Aurélia. Humanismo latino: o Estado brasileiro e as patentes biotecnológicas. In: MEZZAROBA, Orides. Humanismo latino e Estado no Brasil. Florianópolis: Fundação Boiteux; Treviso: Fondazione Cassamarca, 2003.

DIAFÉRIA, Adriana. Patentes de genes e o direito ao progresso econômico, científico e tecnológico. Direito Ambiental em Debate, Rio de Janeiro, v. 1, p. 21-33, 2004.

DÍEZ RIPOLLÉS, José Luis; GARCÍA PÉREZ, Octavio (Coords.). La política legislativa penal iberoamericana en el cambio de siglo: una perspectiva comparada (2000-2006). Montevidéo; Buenos Aires: Editorial IB de f., 2008.

DONNA, Edgardo Alberto. Prologo. In: NAUCKE, Wolfgang; HASSEMER, Winfried; LÜDERSSEN, Klaus. Principales problemas de la prevención general. Traducción por el Dr. Gustavo Eduardo Abosoy la Prof. Tea Low. Montevideo; Buenos Aires: Julio César Faira - Editor, 2004. p. 9-11.

ENGELS, Eve-Marie. El estatuto moral de los animales en la discusión sobre el xenotrasplante. In: ROMEO CASABONA, Carlos et al. Los xenotrasplantes: aspectos científicos, éticos y jurídicos. Granada: Comares, 2002.

FERNANDES, Márcia Santana. Bioética, medicina e direito de propriedade intelectual: relação entre patentes e células-tronco humanas. São Paulo: Saraiva, 2012.

FERREIRA, Ivette Senise. O direito penal ambiental. Disponível em: <http://campus.fortunecity. com/clemson/493/jus/m07-009.htm>. Acesso em: 02 set. 2008. 
FIORILLO, Celso Antonio Pacheco. Curso de direito ambiental brasileiro. São Paulo: Saraiva, 2011.

; DIAFÉRIA, Adriana. Biodiversidade e patrimônio genético no direito ambiental brasileiro. São Paulo: Max Limonad, 1999.

GOMES, Rodrigo Carneiro. O controle e a repressão da biopirataria no Brasil. Revista do Tribunal Regional Federal da Primeira Região, ano 21, n. 2, fev. 2009.

GRECO, Luís. A relação entre o direito penal e o direito administrativo no direito penal ambiental: uma introdução aos problemas da acessoriedade administrativa. Revista Brasileira de Ciências Criminais, São Paulo, v. 14, n. 58, p. 152-194, jan./fev. 2006.

GRECO FILHO, Vicente. Crime: essência e técnica. Boletim do Instituto Manoel Pedro Pimentel, São Paulo, v. 5, n. 21, jul./set. 2002.

GRECO FILHO, Vicente. Tipicidade, bem jurídico e lavagem de dinheiro. In: COSTA, José Faria da (Org.). Direito penal especial, processo penal e direitos fundamentais: visão luso-brasileira. São Paulo: Quartier Latin, 2006.

GRIMALDI, Karina. Tutela jurídica administrativa da biodiversidade de fauna silvestre brasileira e o combate à biopirataria. Revista Brasileira de Direito Ambiental, ano 6, v. 14, p. 147-207, abr./ jun. 2008.

HAFFKE, Bernhard. Reincidencia y medición de la pena. In: SCHÜNEMANN, Bernd (Comp.). El sistema moderno del derecho penal: cuestiones fundamentales. Buenos Aires: B de F, 2012, p. 229-253.

HASSEMER, Winfried. Crítica al derecho penal de hoy: norma, interpretación, procedimento. Limites de la prisión preventiva. Buenos Aires: AD-HOC S.R.L., 1998.

. Fundamentos del derecho penal. Trad. Francisco Muñoz Conde e Luis Arroyo Zapatero. Barcelona: Bosch, 1984.

. Persona, mundo y responsabilidad: bases para uma teoria de la imputación em derecho penal. Trad. Francisco Muñoz Conde e Maria Del Mar Diaz. Santa Fé de Bogotá: Editorial Temis S.A., 1999.

. A preservação do ambiente através do direito penal. Revista Brasileira de Ciências Criminais, São Paulo, v. 22, p. 27-35, 2002.

HATHAWAY, David. A biopirataria no Brasil. In: BENSUSAN, Nurit. Seria melhor mandar ladrilhar? Biodiversidade, como, para que e por quê. Brasília: Ed. da Universidade de Brasília, 2002.

HERINGER, Astrid. Os conhecimentos tradicionais associados e o acesso aos recursos genéticos: um estudo sobre a regulamentação da medida provisória n. 2.186-16/01. Revista Amazônia Legal de Estudos Sócio-Jurídico-Ambientais, Cuiabá, ano 1, n. 2, p. 131-148, jul./dez. 2007. 
HOMMA, Alfredo Kingo Oyama. Extrativismo, biodiversidade e biopirataria na Amazônia. Brasília, DF: Embrapa Informação Tecnológica, 2008.

KERR, Warwick Estevan. Biodiversity: today's and tomorrow's importance. In: VVAA, Diversidade biológica e cultural da Amazônia, Ima Célia Guimarães Vieira, Belém, Museu Paraense Emílio Goeldi, 2009.

LEMOS, Edward Antônio Pinto; ATAÍDE, Raquel Batista de. Patrimônio genético e biotecnologia: interesses do Brasil na ALCA. Verba Juris: Anuário da Pós-Graduação em Direito Universidade Federal da Paraíba Pós-Graduação em Ciências Jurídicas. Editora Universitária UFPB, ano 4, n. 4, p. 329-374, jan./dez. 2005.

LEUZINGER, Márcia Diguez. A importância das áreas protegidas e das comunidades tradicionais na conservação da biodiversidade. Direito Ambiental em debate, Rio de Janeiro, v. 2, p. 281-294, 2004.

LÓPEZ ALFONSÍN, Marcelo. Derecho ambiental. Buenos Aires: Ástrea, 2012.

NAUCKE, Wolfgang; HASSEMER, Winfried; LÜDERSSEN, Klaus. Principales problemas de la prevención general. Traducción por el Dr. Gustavo Eduardo Abosoy la Prof. Tea Low. Montevideo; Buenos Aires: Julio César Faira - Editor, 2004.

OTÁVIO, Chico. Inventário Amazônia: ocupação, preservação e futuro. Rio de Janeiro: Desiderata, 2007.

PONTES, Jorge B. Projeto Drake: a Polícia Federal contra a biopirataria. Revista ECO21, ed. 83, out. 2003. Disponível em: <http://www.eco21.com.br/textos/textos.asp?ID=572>. Acesso em: 28 out. 2011.

POSTIGLIONE, Amedeo. Global Environmental Governance: the need for an International Environmental Agency and an Internacional Court of the Environmental. Bruxelas: Etablissements Emile Bruylant, 2010.

RABENHORST, Eduardo Ramalho. O valor do homem e o valor da natureza. Breve reflexão sobre a titularidade dos direitos morais. In: SILVEIRA, Rosa Maria Godoy et al. (Orgs.). Educação em direitos humanos: fundamentos teórico-metodológicos. João Pessoa: UFPB, 2007. p. 209230. Disponível em: <http://www.redhbrasil.net/documentos/bilbioteca_on_line/educacao_em_ direitos_humano s/14\%20-\%20Cap\%202\%20Artigo\%206.pdf $>$. Acesso em: 01 dez. 2012.

RESTA, Giorgio. O acesso ao material biológico humano com fins de pesquisa e de aproveitamento industrial: questões relativas ao consentimento e à responsabilidade na perspectiva do direito comparado. In: MARTINS-COSTA, Judith; MÖLLER, Letícia Ludwig. Bioética e responsabilidade. Rio de Janeiro: Forense, 2009, p. 145-204.

ROCHA, Letícia Kolton. Um estudo crítico sobre a proteção dos conhecimentos tradicionais associados à biodiversidade. Revista Brasileira de Direito Ambiental, ano 6, v. 24, p. 93-133, out./ dez. 2010. 
RODRIGUES JÚNIOR, Edson Beas. Tutela jurídica dos recursos da biodiversidade, dos conhecimentos tradicionais e do folclore: uma abordagem de desenvolvimento sustentável. Rio de Janeiro, Elsevier, 2010.

ROXIN, Claus. Derecho penal: parte geral: fundamentos, la estructura de la teoria del delito. Trad. Diego-Manuel Luzón Peña. Madrid: Civitas, 1997. t. 1.

. Derecho penal: parte geral: fundamentos, la estructura de la teoria del delito. Trad. DiegoManuel Luzón Peña. Navarra: Rodona Industria Gráfica, 2007. t. 1.

. Fundamentos político-criminales del derecho penal. 1. ed. Buenos Aires: Hammurabi, 2008.

¿Es la protección de bienes jurídicos una finalidad del derecho penal? In: HEFENDEHL, Roland (Ed.). La teoría del bien jurídico ¿Fundamento de legitimación del derecho penal o juego de abalorios dogmático?. Trad. Iñigo Ortiz de Urbina Gimeno. Madrid: Marcial Pons, 2007. p. 443-458.

. La teoria del delito en la discusión actual. Trad. Manuel A. Abanto Vasquez. Lima: Ed. Jurídica Grijley E. I. R. L., 2007.

SANTILLI, Juliana. Acesso aos recursos genéticos e aos conhecimentos tradicionais associados à biodiversidade: aspectos jurídicos. Revista Brasileira de Direito Ambiental, São Paulo, ano 1, v. 3, p. 21-65, jul./set. 2005.

- Biodiversidade e conhecimentos tradicionais associados: novos avanços e impasses na criação de regimes legais de proteção. Revista de Direito Ambiental, São Paulo, v. 29, n. 8, p. 83102, mar. 2003.

. Socioambientalismo e novos direitos: proteção jurídica à diversidade biológica e cultural. São Paulo: Ed. Fundação Peirópolis, 2005.

SCHÜNEMANN, Bernd. Aspectos puntuales de la dogmática jurídico-penal. Bogotá, Grupo Editorial Ibañez, 2007.

. De un concepto filológico a un concepto tipológico del dolo. In: SCHÜNEMANN, Bernd. Temas actuales y permanentes del derecho penal despues del milenio. Madrud: Tecnos, 2002. p. 97-111.

. La función del principio de culpabilidad en el derecho penal preventivo. In: SCHÜNEMANN, Bernd (Comp.). El sistema moderno del derecho penal: cuestiones fundamentales. Buenos Aires: B de F, 2012. p. 179-228.

¿Ofrece la reforma del derecho penal económico alemán un modelo o un escarmiento? In: SCHÜNEMANN, Bernd. Obras. Buenos Aires: Rubinzal-Culzoni, 2009. t. 2. p. 218-242.

. La punibilidad de las personas jurídicas desde la perspectiva europea. In: SCHÜNEMANN, Bernd. Obras. Buenos Aires: Rubinzal-Culzoni, 2009. v. 2, p. 114-162. 
. La teoria de la protección del bién jurídico como base del derecho penal en la época de la globalización. In: SCHÜNEMANN, Bernd. Obras. Buenos Aires: Rubinzal-Culzoni, 2009. t. 2. p. 64-112.

SHIVA, Vandana. Biopirataria. A pilhagem da natureza e do conhecimento. Petrópolis: Vozes, 2001.

SILVA, Marina da. Biodiversidade: oportunidade e dilema. Disponível em: <www.amazonlink.org/ gd/diversidade/SenadoraMarinaPORT.doc>. Acesso em: 16 out. 2012.

SILVA, Sebastião B. Direitos Ambientais também são Direitos Humanos. Disponível em: <http:// www.dhnet.org.br/educar/academia/coloquio/meioambiente_sebastiao.html>. Acesso em: 12 jun. 2011.

VEIGA, José Eli da. A emergência socioambiental. São Paulo: Ed. SENAC, 2007.

WACHOWICZ, Marcos; ROVER, Aires José. Propriedade intelectual: conhecimento tradicional associado a biopirataria. In: IACOMINI, Vanessa (Coord.). Propriedade intelectual e biotecnologia . Curitiba: Juruá, 2007.

WANDSCHEER, Clarissa Bueno. Reflexões sobre a biopirataria, biodiversidade e sustentabilidade. In: SILVA, Letícia Borges da; OLIVEIRA, Paulo Celso de (Orgs.). Socioambientalismo: uma realidade: homenagem a Carlos Frederico Marés de Souza Filho. Curitiba: Juruá, 2007. p. 63-78.

ZAFFARONI, Eugenio Raúl. La Pachamama y el humano. Buenos Aires: Ediciones Madres de Plaza de Mayo, 2012.

ZAMBRANO PASQUEL, Alfonso. La reciente política legislativa penal en Ecuador. In: DÍEZ RIPOLLÉS, José Luis; GARCÍA PÉREZ, Octavio (Coords.). La politica legislativa penal iberoamericana en el cambio de siglo: una perspectiva comparada (2000-2006). Montevidéo; Buenos Aires: Editorial IB de f., 2008. 